This article has been scanned by iThenticat No plagiarism detected

Volume 3, Issue 5, October 2021

p. 49-66

\title{
ATTITUDES OF SECONDARY SCHOOL TEACHES IN EAST JERUSALEM TOWARDS EMPLOYING ALTERNATIVE ASSESSMENT STRATEGIES IN TEACHING
}

http://dx.doi.org/10.47832/2757-5403.5-3.5

lubna NASRALLAH 1 \& Mirvat ABU ASABBIGBARIEH ${ }^{2}$

\begin{abstract}
:
The study aimed to identify the attitudes of secondary school teachers in East Jerusalem towards employing alternative assessment strategies in teaching, according to gender variables, years of service, educational material, and the classes they teach. In order to verify the objectives of the study, the researchers used the descriptive analytical approach by adopting a questionnaire (Bani Khalaf, 2019) with some modifications to be made in line with the current study, and the number of its paragraphs reached (32) paragraphs distributed over three areas. The questionnaire was applied to a sample of (143) teachers male and female, from the study community consisting of (780) male and female teachers.

The results of the study concluded that the attitudes of secondary school teachers in East Jerusalem towards employing alternative assessment strategies were positive and to a large extent, with the overall tool obtaining an arithmetic mean of (3.74), as well as the presence of statistically significant differences due to gender variables, years of service, educational material, and grades that were taught. The results showed positive statistical differences in favor of females with the variable of gender and for those with longer experience among teachers of the twelfth grade, The results showed positive statistical differences in favor of females with the variable of gender and for those with longer experience among teachers of the twelfth grade and in favor of teachers of other subjects over teachers of science, mathematics and languages.
\end{abstract}

Key words: Attitudes, High Schools In East Jerusalem, Alternative Assessment Strategies.

\footnotetext{
${ }^{1}$ Dr. , Arab American University, Palestine, lubtamnas@gmail.com, https://orcid.org/0000-0001-9464-9596

${ }^{2}$ Dr. , Arab American University, Palestine, Yossi2007@yahoo.com, https://orcid.org/0000-0001-8489-7545
} 


\title{
اتجاهات معلمي المرحلة الثانوية في القدس الثرقية نحو توظيف استراتيجيات التّقويم

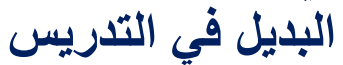

\author{
لبنى زاهي التّميمي نصر الله 3

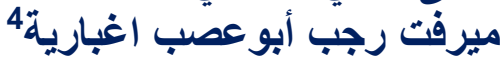

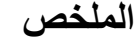

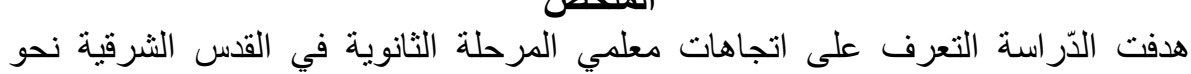

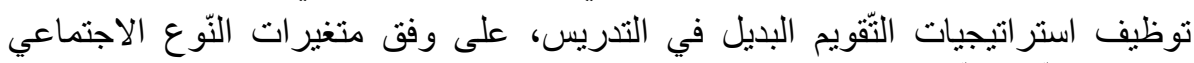

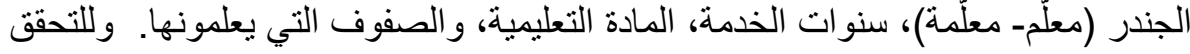

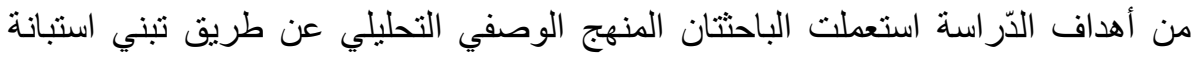

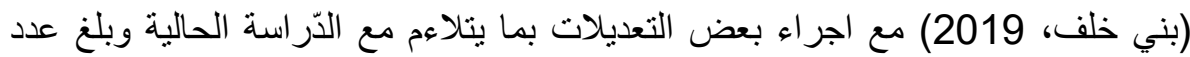

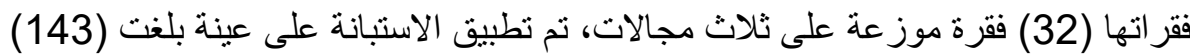

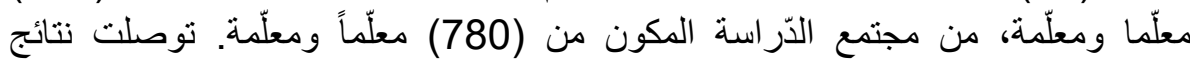
الدّر اسة إلى أن اتجاهات معلمي المرحلة الثانوية بالقدس الثرقية نحئ نحو نوظيف استر التيجيات

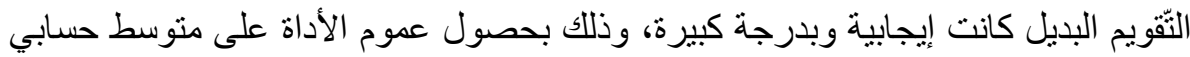

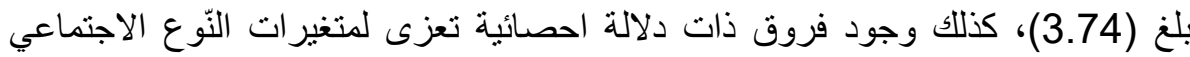

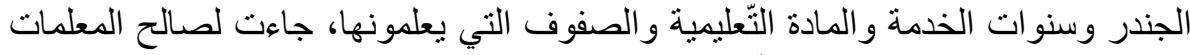

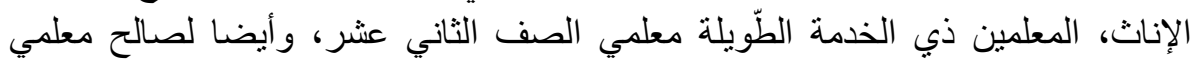

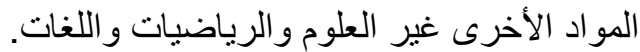
الكلمات المفتاحية: اتجاهات، المدارس الثنانوية في القيات القدس الثرقية، استراتيجيات التقويم

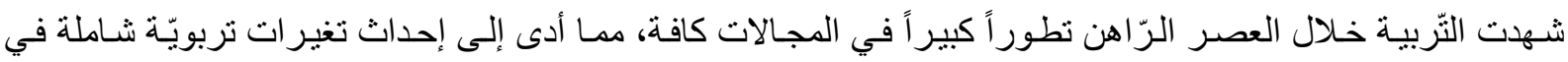

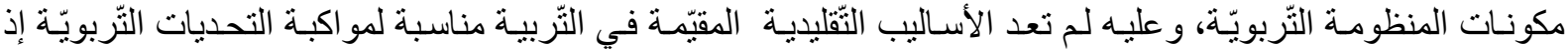

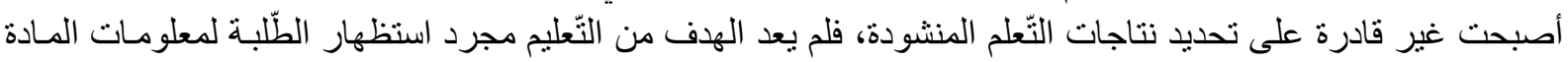
ومن ثم إعادة سردها، إنما تعدى ذللك إلى إعداد طلبة يملكون كفايات متتوعة تمكنهم من مسـايرة الحياة العلميـة العملية

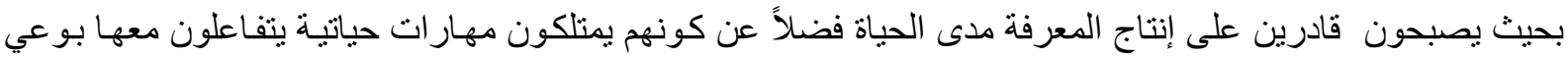

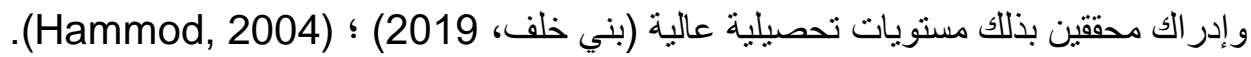
وبما أن عملية التّقويم هي الوسيلة الوحيدة التي تتيح فرصة النّعرف على مدى تحقيق الأهداف، كذللك تعدُّ الوسبلة الفعّالة

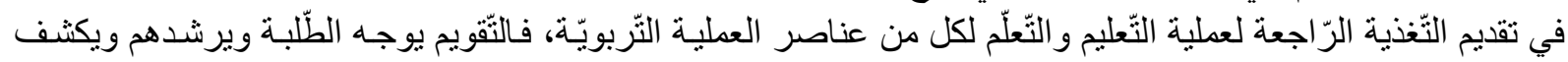

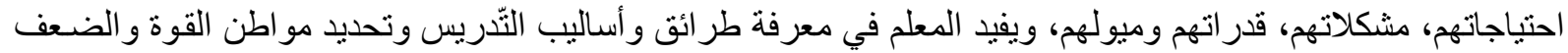

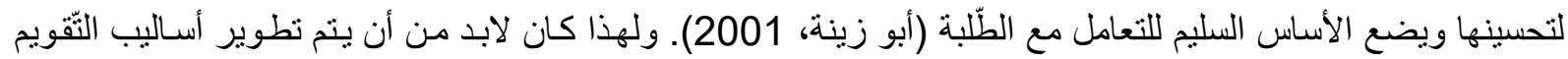

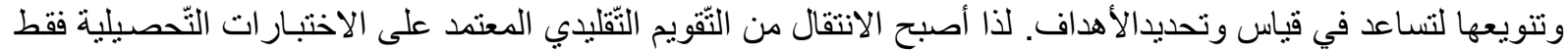

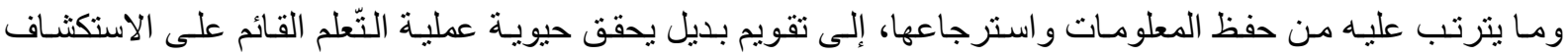

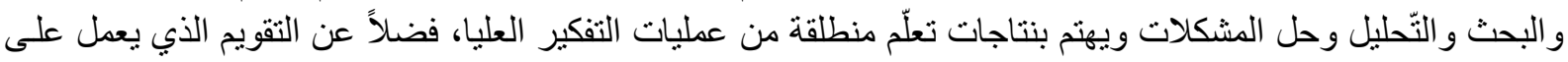

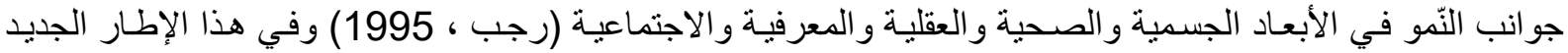
تصبح الاختبار ات التّحصيلية أداة من بين الأدوات المتعددة لقياس نمو وتعلم الطّلبة القادرين على العيش في مجتمع القرن 
الحادي و العشرين، القائم على اقتصاد المعرفة والعولمة (Craw, 2009). إذ لوحظ في الدّول المتقدمة أنّ التّعلم النّوعي

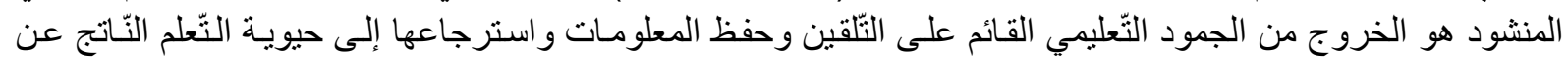

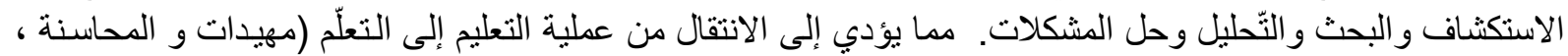

. (2009

\section{إثكالية الآراسة}

أشارت العديد من الدّراسات إلى موضوع التّقويم البديل ودرجة استعماله و إمكانية توظيفه في العملية التّدريسية واتجاهات

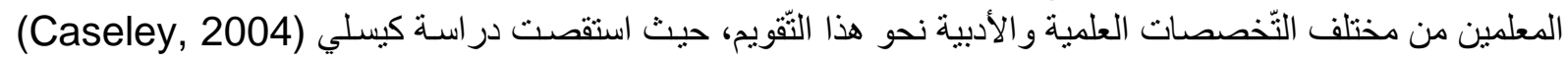

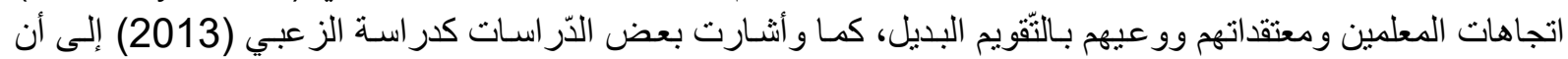

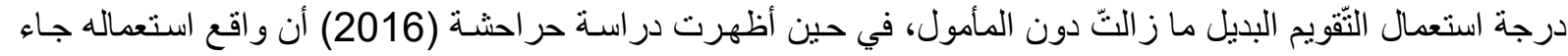

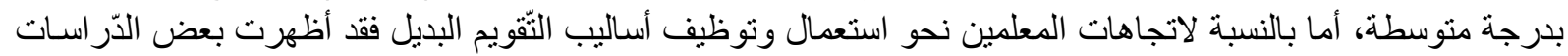

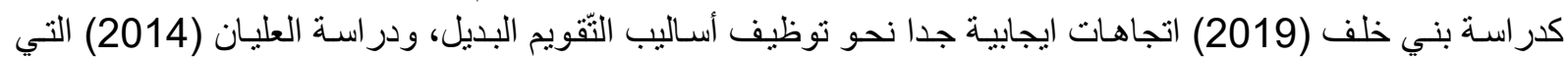
أظهرت اتجاهات ايجابية بدرجة عالية، لذلك برزت هذه الذّر اسة استكمالا لرؤية الباحثين في أهمية توظيف التّويم البديل

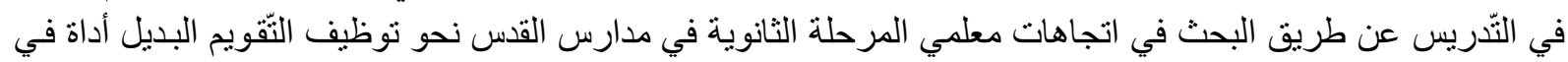

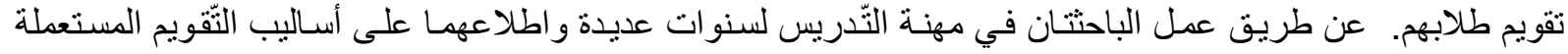

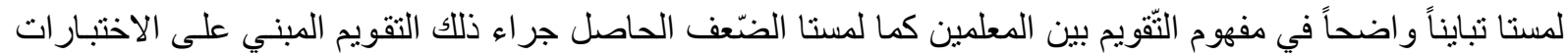

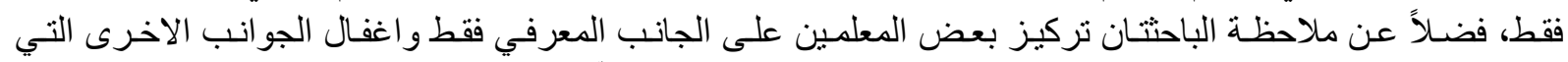

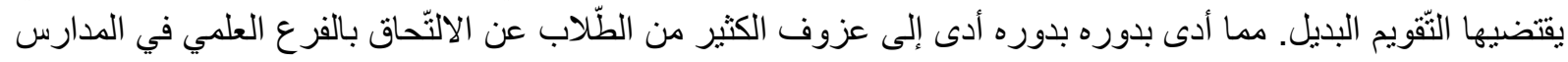

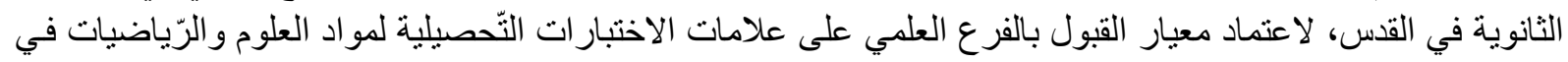

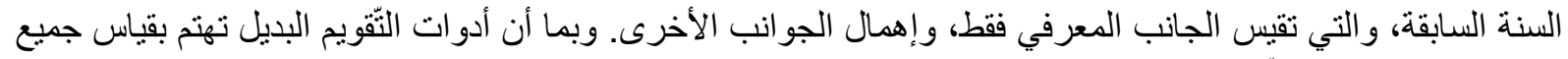

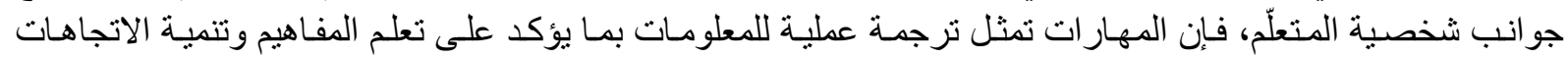

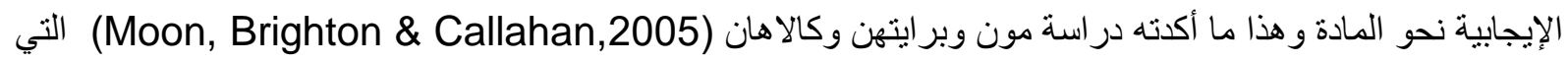

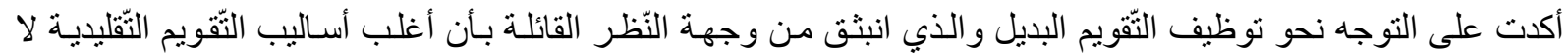

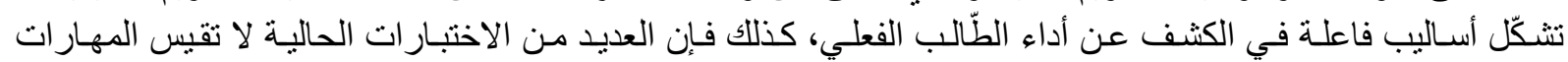

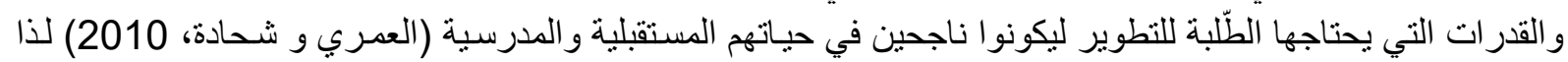

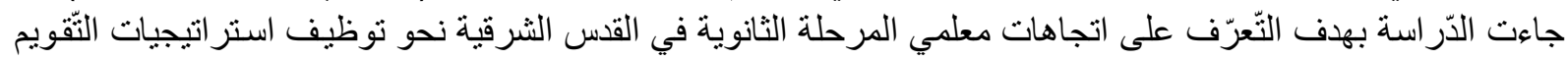

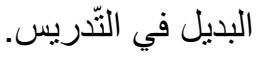

أسئلة الآر اسـة:

وبناءً على ما تمّ طرحه يمكن تحديد إثكالية الدّر اسة بالسؤال الآتي:

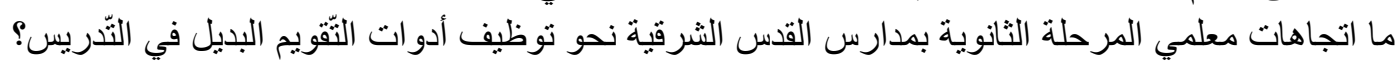
وللتحقق من الهدف الرّئيس يتوجب صياغة النيانية الفرضيات الآتية:

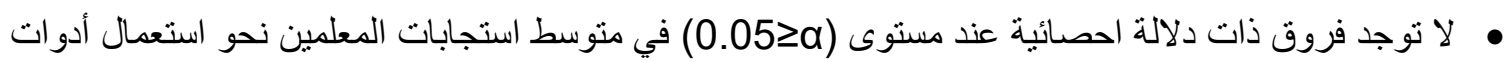
التّقويم البديل تعزى لمتغير الجندر (معلّم، معلّمة).

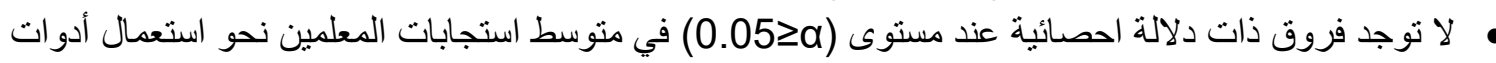

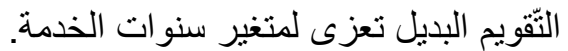

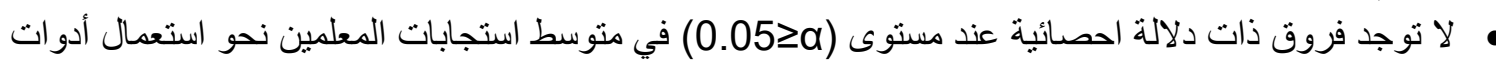
التقّويم البديل تعزى لمتغير المادة التّعليمية.

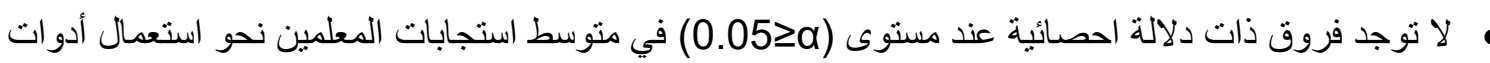
التّقيم البديل تعزى لمتغير الصف دات دلة الذي يعلمه. 
.TTITUDES OF SECONDARY SCHOOL TEACHES IN EAST JERUSALEM TOWARDS

MPLOYING ALTERNATIVE ASSESSMENT STRATEGIES IN TEACHING

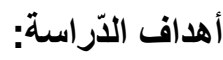 \\ تهدف الدّر اسة إلى استقصاء:
}

اتجاهات المعلمين نحو توظيف استراتيجيات التّقويم البديل في التّدريس في المدارس الثانوية في مدينة القدس الثرقية.

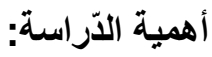

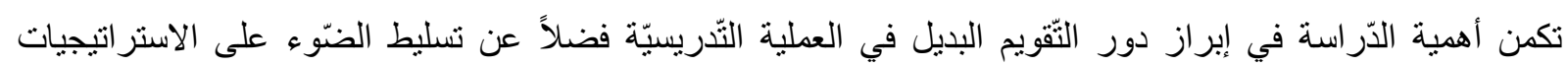

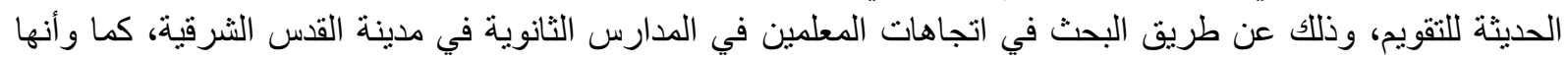

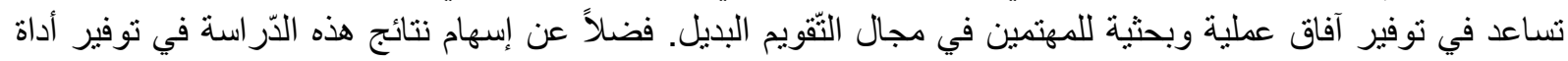

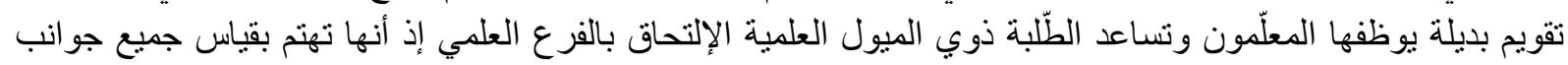

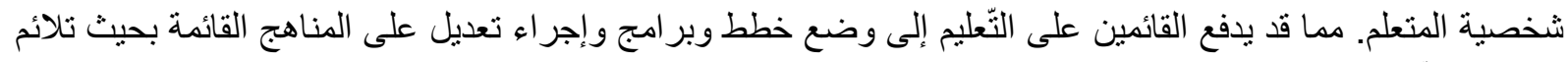

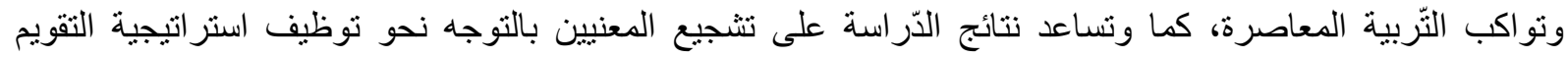

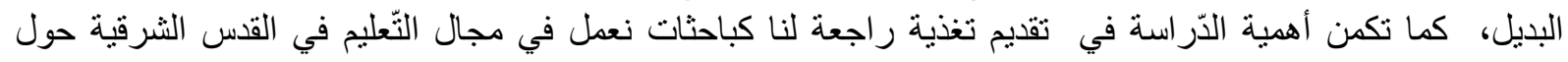

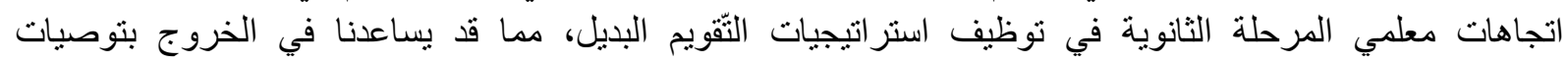

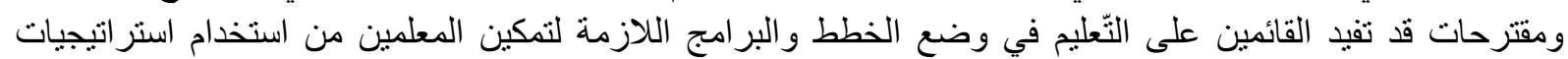
تقويم بديل تو اكب منطلبات العصر و الثّربية المعاصرة التي تدعو إلى تربية إبداعية حوارية وليس تربية تلقينيه بنكية.

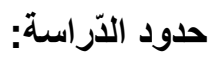
الحدود الموضوعية: اتجاهات معلمي المرحلة الثانوية في القس الثرقية نحو توظيف استراتيجيات التقويم البديل في التدريس.

• • الحدود المكانية: اقتصرت الدّر اسة على المدارس الثانوية الحكومية في مدينة القدس الثرقية.

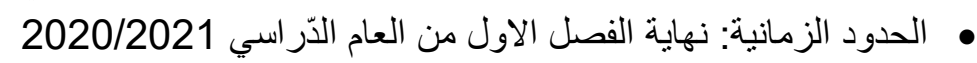
• الحدود البشرية: اقتصرت على معلمي المرحلة الثانوية في المدارس الحكومية في مدينة القس الثرقية.

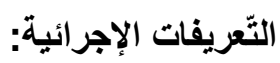

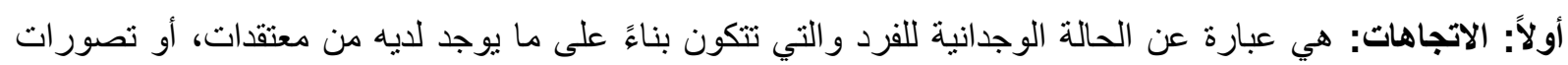

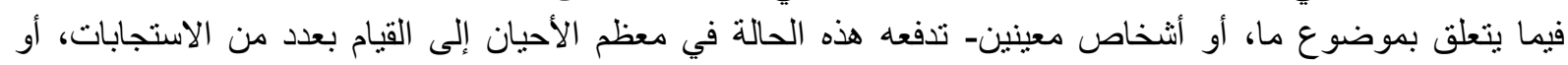

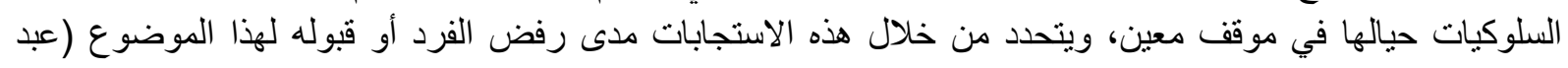

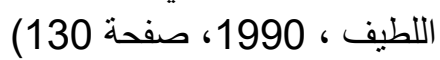

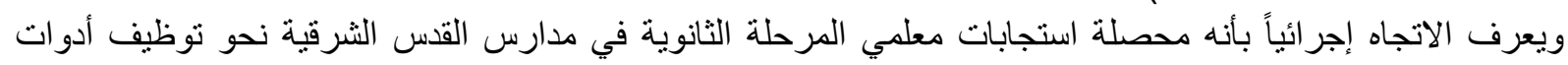
التّقويم البديل، ويعبر عن ذللك احصائيا بالدّرجة التي ستحصل عليها التها الفئة المستهدفة نتيجة استجابتهم لعبارات المقياس المعد لهذا الغرض.

ثانياً التّقويم البديل: هو التّقيم الذي يُنجز به الطّلبة مهمات مشابهة للواقع الحياتي الذي يعيشونه، والتي تُظهر نوظيف ذا

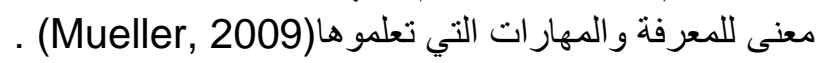

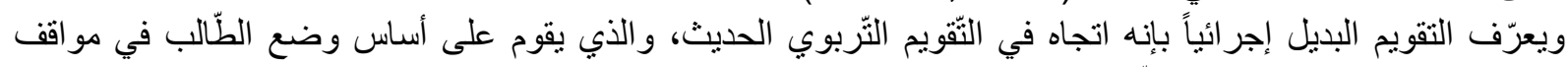

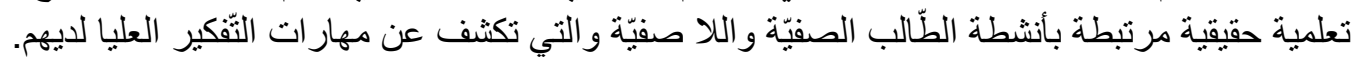

أولاً: الحدود النّظرية:

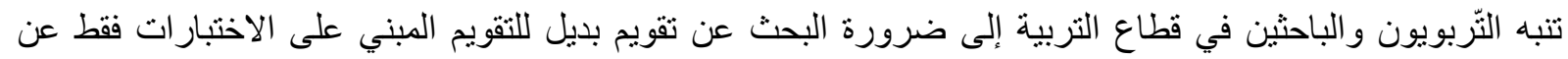

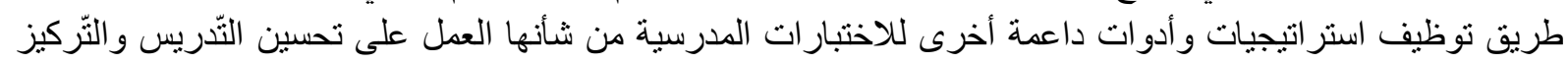

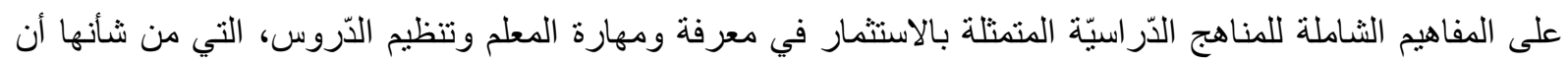


تؤدي إلى تطوير التعليم وتحسينه. بحيث لا يقتصر التّقويم على اختبار ات الورقة و القلم فقط و إنما يتعدى ذلك إلى أساليب أخرى من شأنها تحقيق تعلم نوعي متمركز حول الطّالب وبهذا يتم تحقيق التربية المعاصرة (مهيدات و المحاسنة ، . (2009

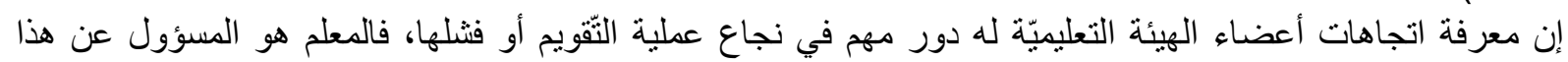

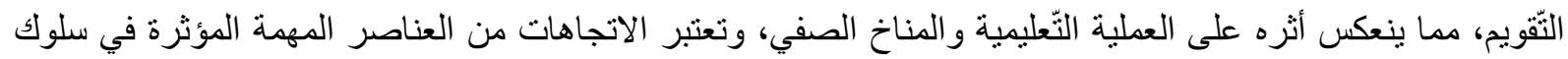

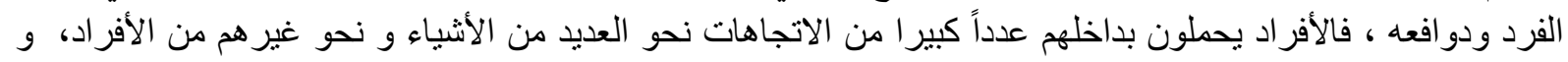

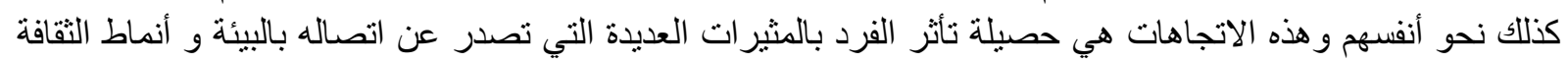

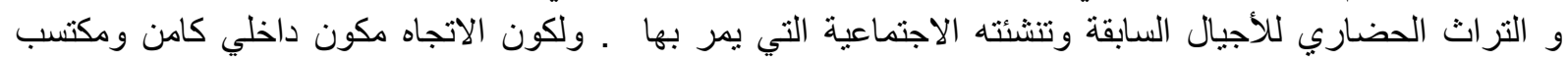

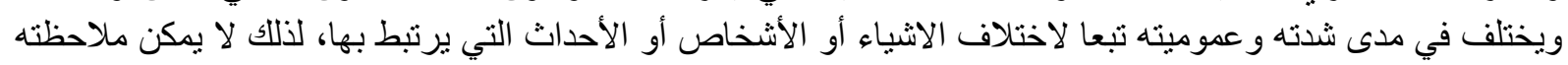

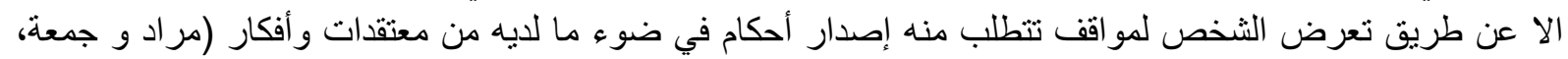

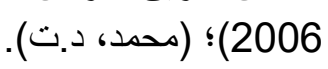
بعد أن تنبه التربويون أصحاب المدرسة السلوكية التي تؤكد ضرورة الانتقال من الأهداف المحددة بدقة القابلة للملاحظة

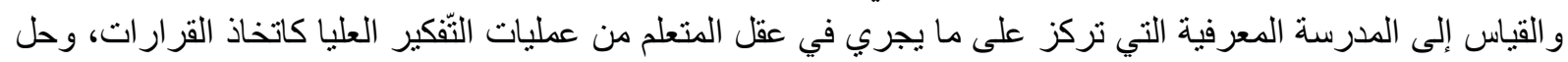

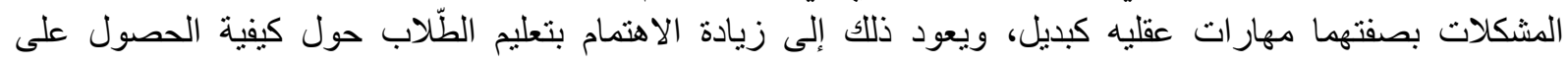

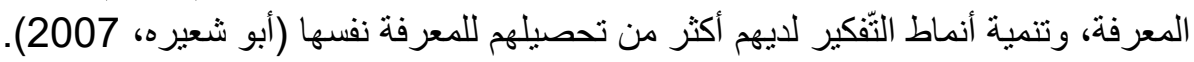

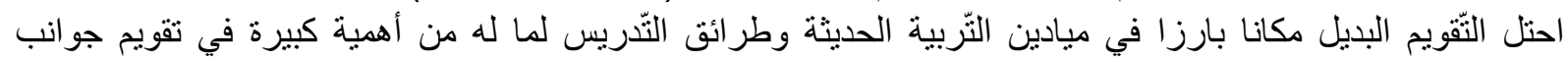

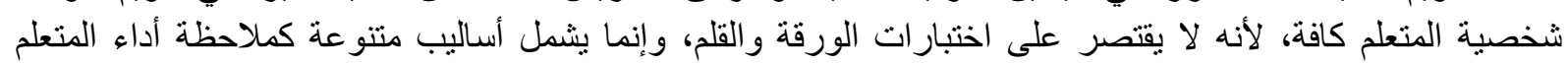

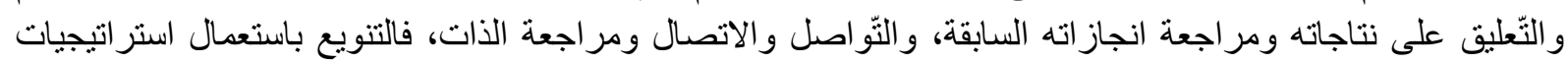

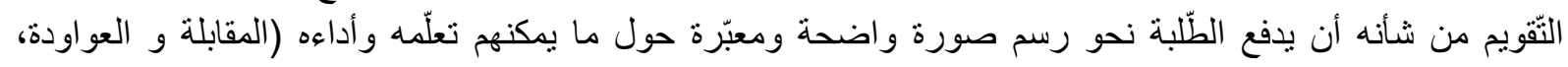

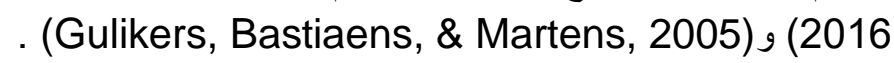

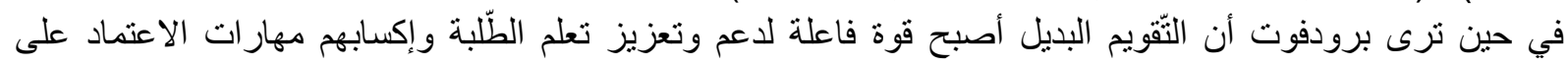

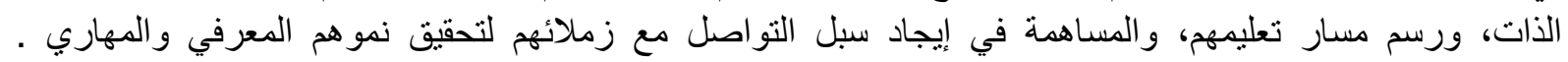

(Broadfoot, 2004) ولقد تعددت المفاهيم التي تثير إلى التّويم البديل نظرا لحداثته، إذ نلاحظ الكثير من المصطلحات المر ادفة مثل التّقويم

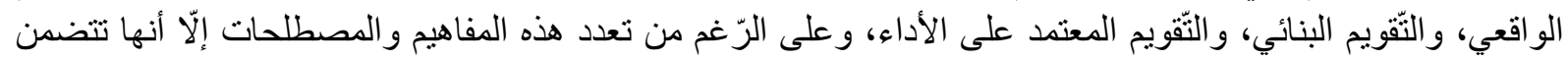

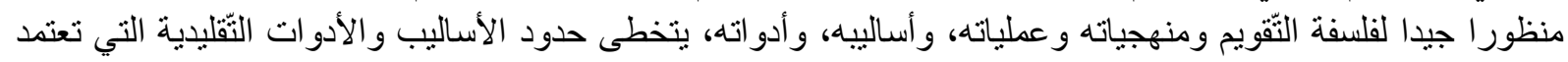
بشكل أساسي على اختبار ات الورقة و القلم (علام، 2004).

\section{نبذة عن المدارس الثانوية في القدس الثرقية}

ييلغ عدد الددارس الثانوية الحكومية في القس الثرقية حوالي 27 مدرسة، منها ما هو خاص بالذكور، ومنلها للإناث،

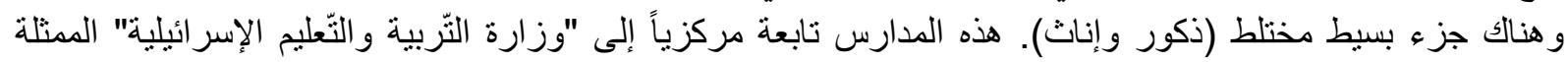

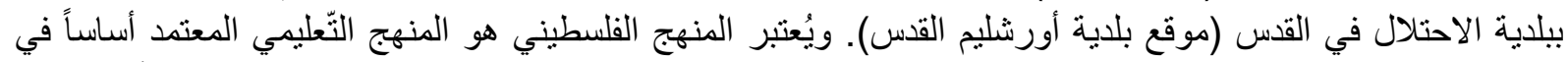

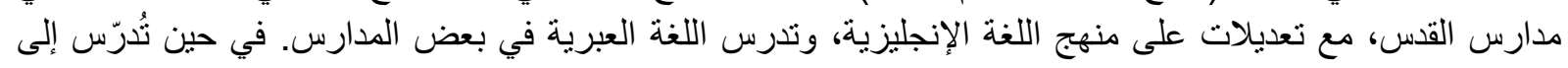

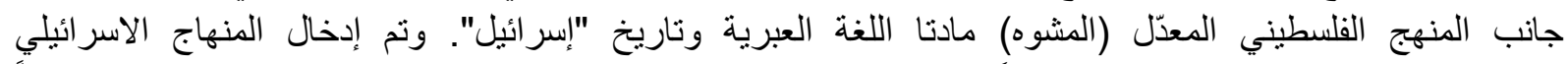

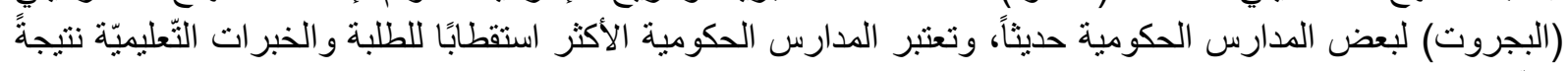

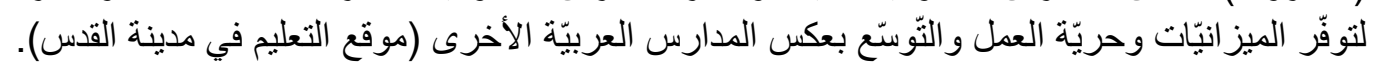

ثانياً: الآّراسات السابقة:

تعددت الدّر اسات التي تناولت موضوع التّقويم البديل بمسمياته المختلفة، ففي دراسة أجر اها بني خلف (2019) و التي

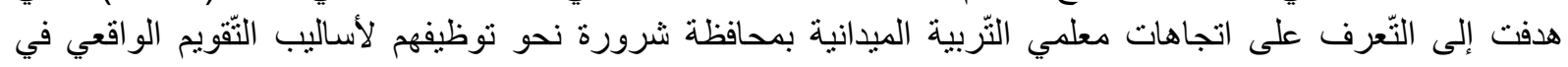

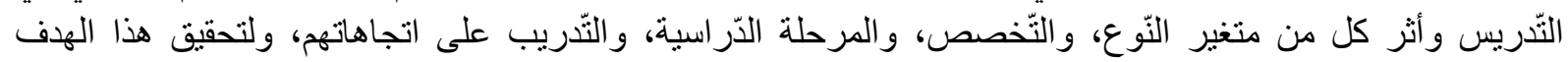

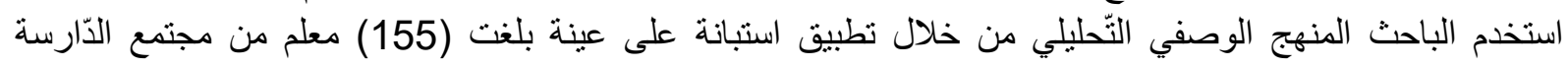




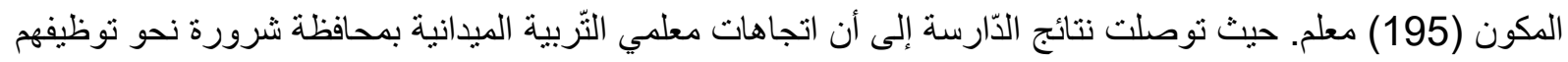

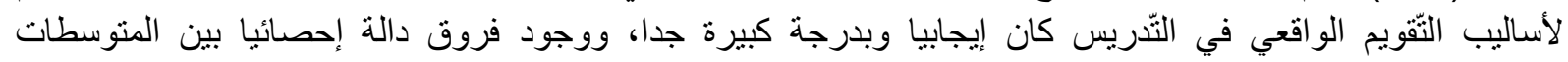

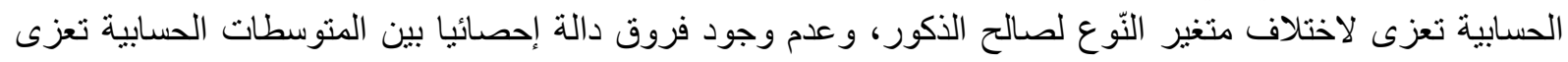
للتخصص و المرحلة الذّر اسبة والتّريب.

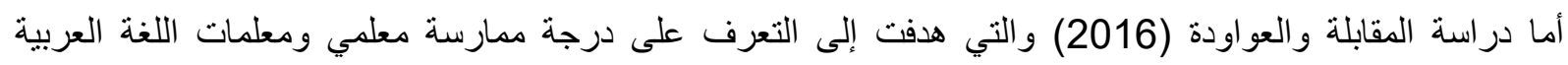

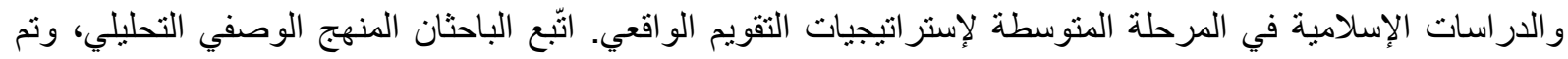

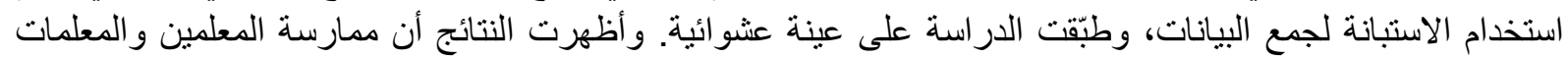

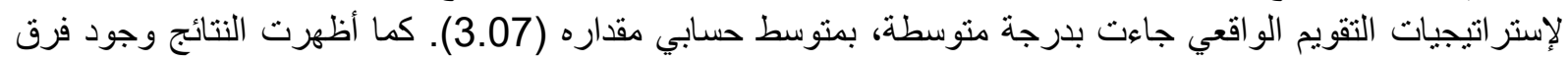

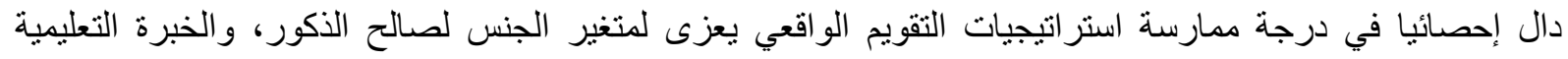

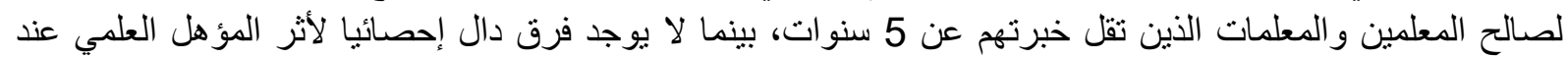
مستوى الدلالة 0.05. وفي دراسة لحر احشة (2016) هدفت إلى التّعرف على واقع استخدام معلمي العلوم لاستراتيجيات التّقويم البديل و أدو اته

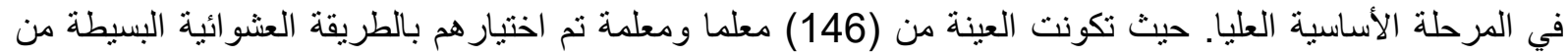

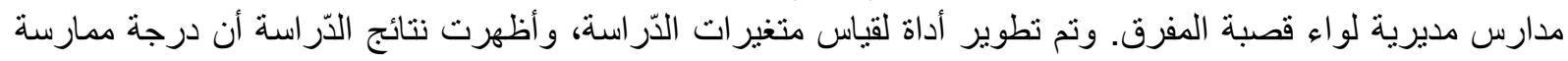

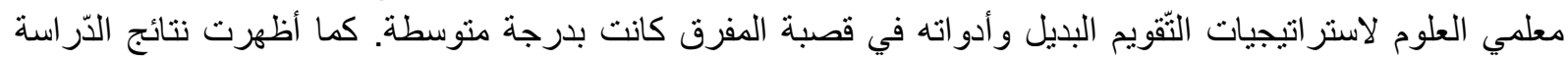

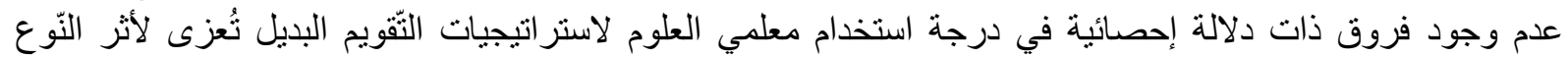
الاجتماعي و المؤهل العلمي و الخبرة. وأجرى العليان (2014) دراسة هدفت إلى التّعرّف على اتجاهات معلمي الرّبياضيات بالمرحلة المنوسطة نحو استخدام

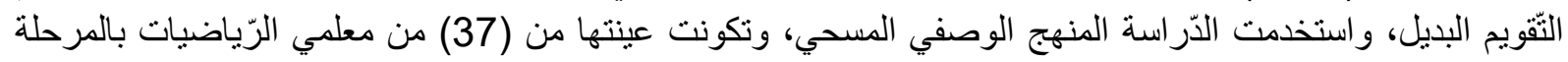
المنوسطة في المدارس الحكومية في محافظة الدّو ادمي، نوصلت إلى أنّ اتجاهات عينة الدّر اسة نحو استخدام التّقويم البديل إيجابية بدرجة عالية. أما دراسة الزعبي (2013) هدفت إلى الكثنف عن درجة معرفة وممارسة معلمي الرّياضيات لاستراتيجيات التقويم

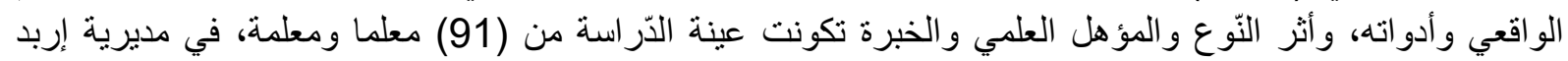

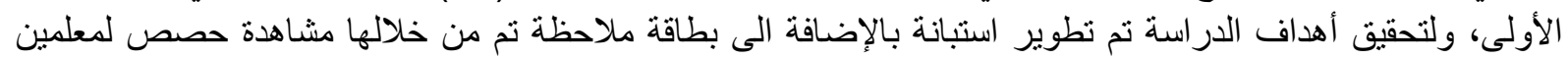

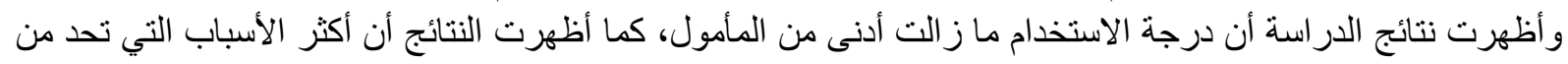

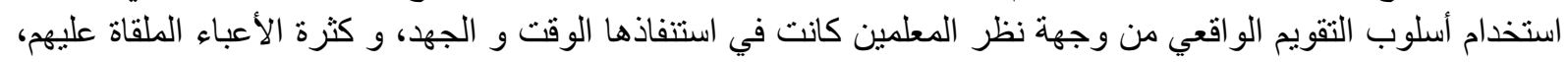

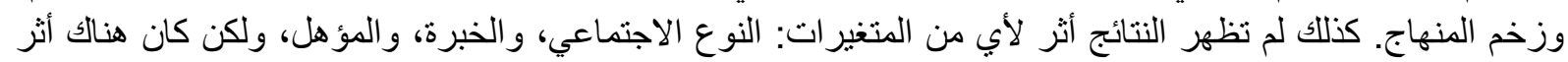

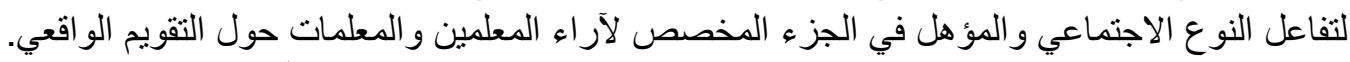

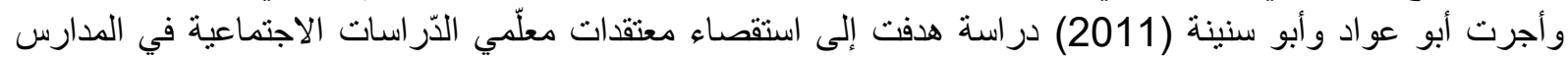

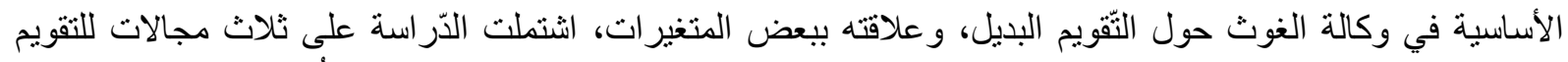

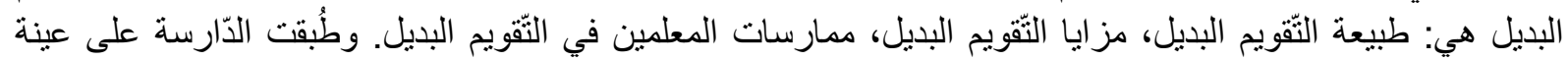

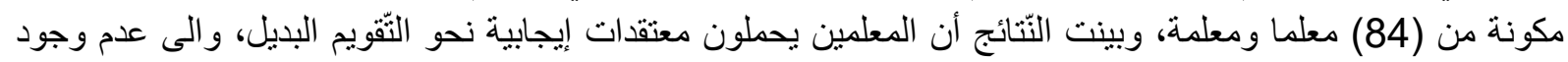

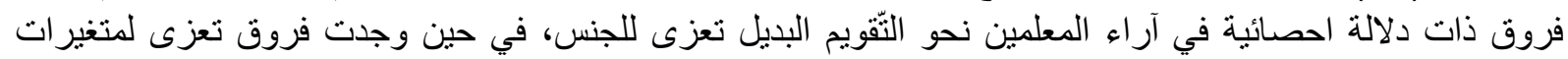

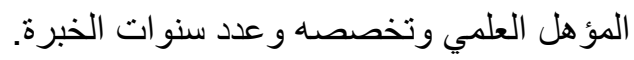
وفي در اسة أخرى للزبيدي (2011) و التي هدفت إلى التّعرّف على و اقع استخدام معلمي ومعلمات العلوم لأساليب التّقويم

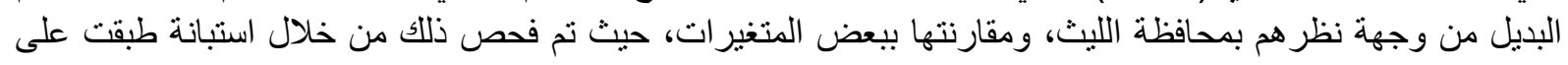

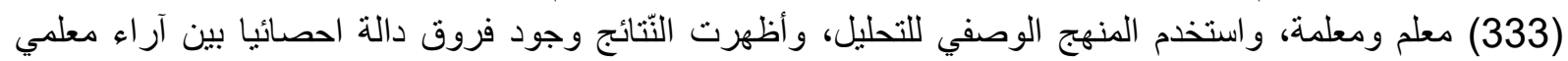

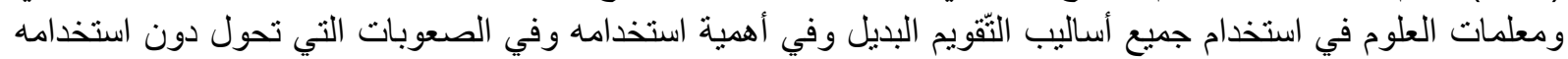

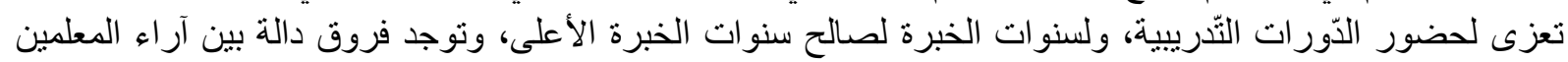

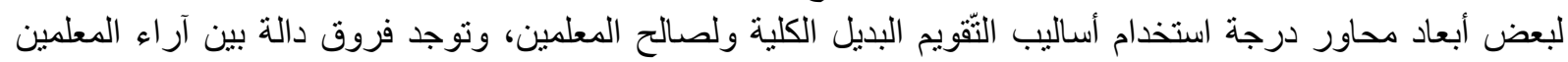

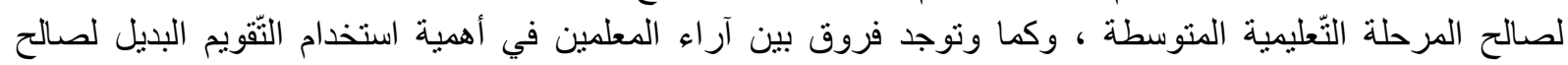


المؤهل التّربوي ولسنوات الخبرة، بينما لا توجد فروق دالة احصائيا بين آراء المعلمين في جميع أساليب استخدام التّقويم البديل تعزى لنوع المؤ هل الدّر اسي. أجرى إتسي (Etsey, 2000) دراسة هدفت إلى فحص اتجاهات وممارسات المعلمين نحو استخدام أساليب التّقويم

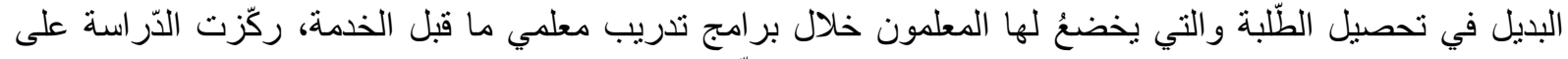

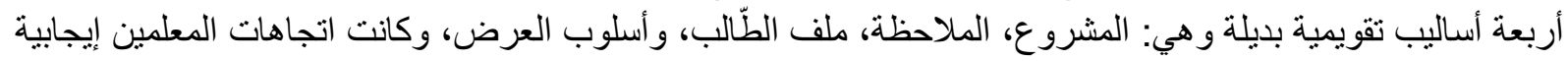
نحو استخدام أساليب التّقويم البديلة.

التّليق على الدّراسات السابقة وأهميتها للاراسة الحالية:

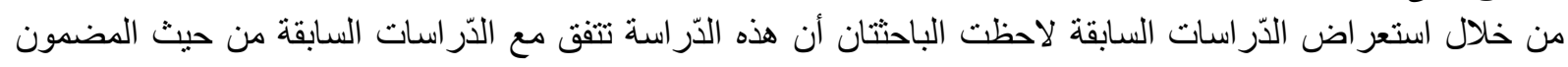

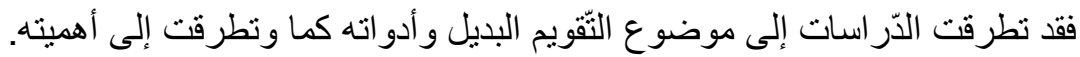
واختلفت عن الدّراسات السابقة من حيث:

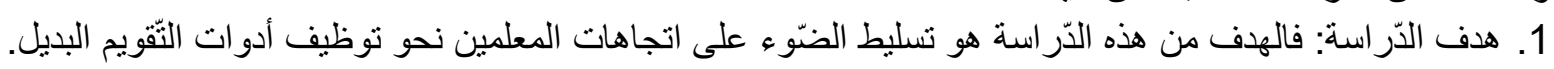

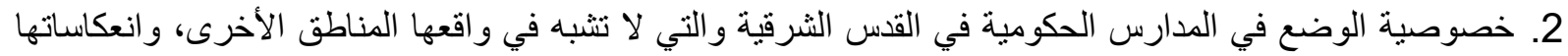
التّربوية على عمليتي التعليم و التعلّم.

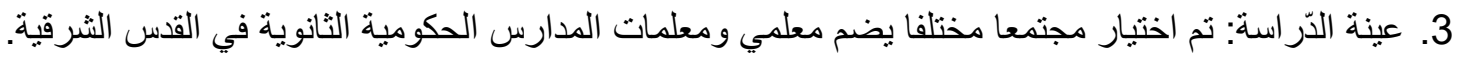

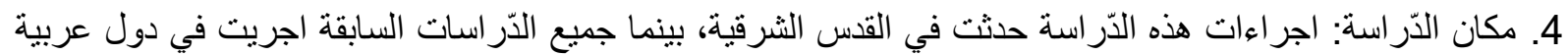
وأجنبة.

جانب إفادة الآّراسة الحالية من الدّراسات السابقة بالعديد من النّقاط منها: ba a اكتسبت الباحثنان رؤية عميقة في مفهوم التقويم البديل ومعطيات توظيفه في عمليني التعليم و التعلّم.

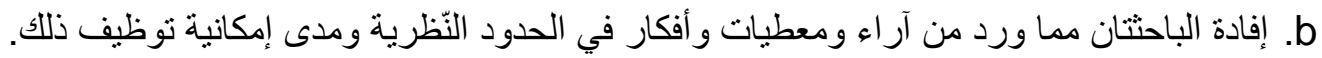

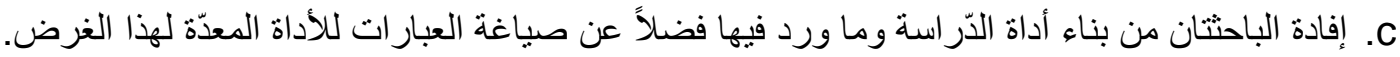

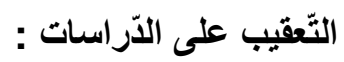

أجريت دارسات عديدة مشابهة إلى حدٍ ما الدّارسة الحالية، كثفت اتجاهات معلمين رسميين في بلدان مختلفة نحو استخدام

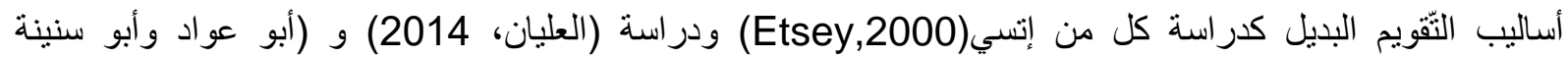

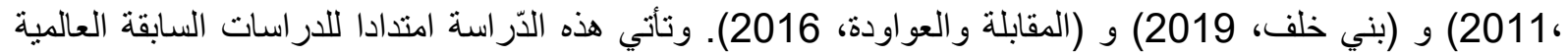
و المحلية التي تتاولت موضوع التّقويم البديل كمتغير يجب الاهتمام به و علاقته بالمتغيرات الدّيموغر افية، لتعمل الدّر استة

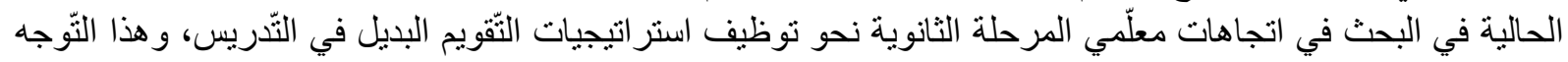

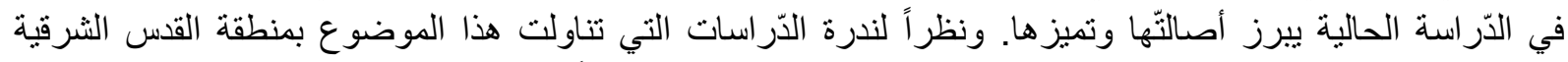

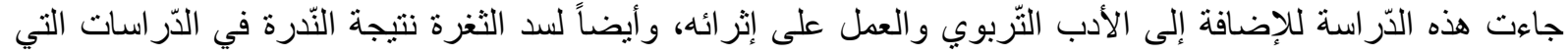

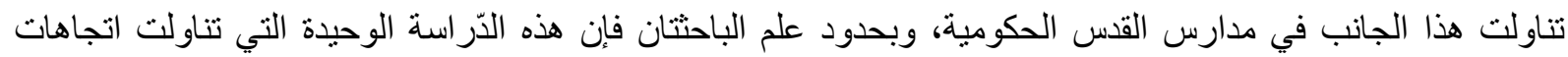

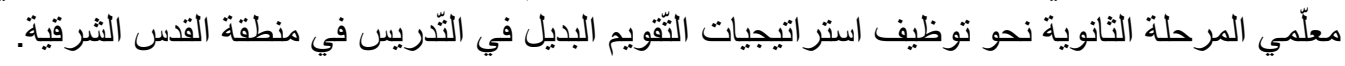

\section{منهجية وإجراءات الدّراسة \\ منهجية الآراسة:}

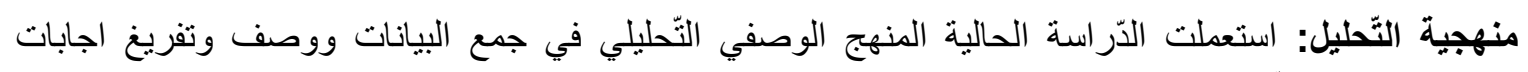

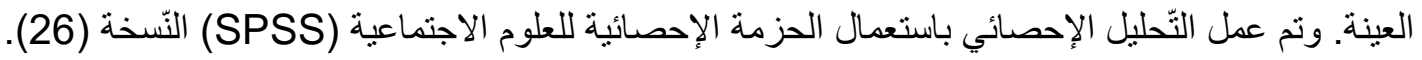

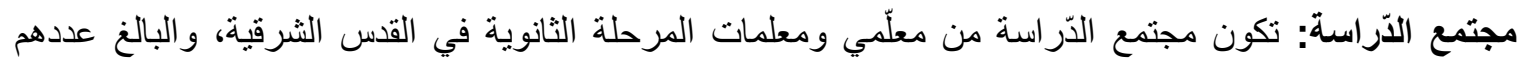

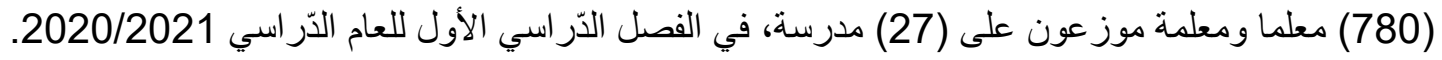


• عينة الدّراسة: تم اختيار عينة الدّر اسة من مجتمع الدّر اسة الأصلي، حيث بلغت العينة (143) معلما ومعلمة من

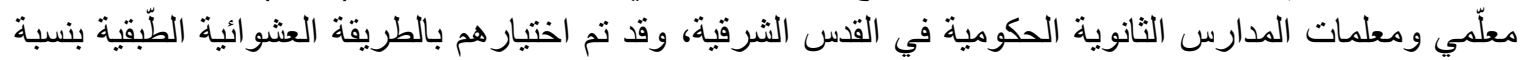

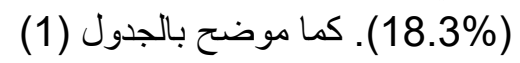

جدول (1) يبين توزيع عينة الدّر اسة على المتغير ات الدّاتيمغرافية ونسبها المئوية:

\begin{tabular}{|c|c|c|c|c|}
\hline النسبة المئويةة\% & التّكر ار & الفئة & المتغير & الرّقم \\
\hline 35.7 & 51 & معلم & \multirow{2}{*}{ 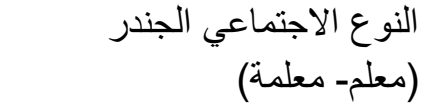 } & \multirow[t]{2}{*}{1} \\
\hline 64.3 & 92 & معلمة & & \\
\hline 10.5 & 15 & أقل من 5 سنوات & \multirow[t]{3}{*}{ عدد سنو ات الخدمة } & \multirow[t]{3}{*}{2} \\
\hline 24.5 & 35 & أكثر من 5 و أقل من 10 & & \\
\hline 65.0 & 93 & 10 سنو ات فأكثر & & \\
\hline 27.3 & 39 & لغات & \multirow{4}{*}{ المعلم } & \multirow[t]{4}{*}{3} \\
\hline 20.3 & 29 & العلوم & & \\
\hline 17.5 & 25 & الرّياضيات & & \\
\hline 35.0 & 50 & أخرى & & \\
\hline 24.5 & 24.5 & صف العاشر & \multirow[t]{3}{*}{ الصف الذي تعلمه } & \multirow[t]{3}{*}{4} \\
\hline 28.0 & 28.0 & صف الحادي عشر & & \\
\hline 47.6 & 47.6 & صف الثاني عشر & & \\
\hline
\end{tabular}

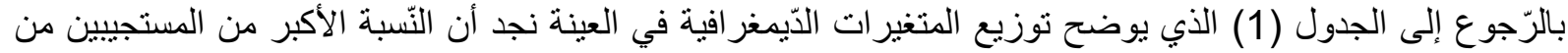

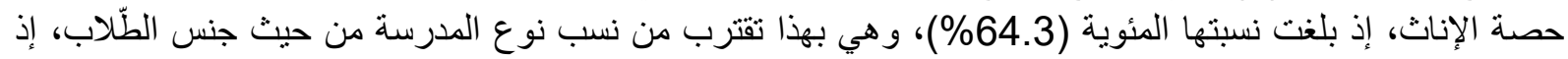

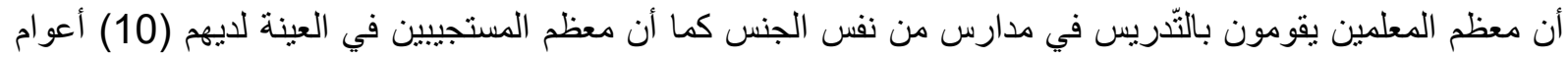

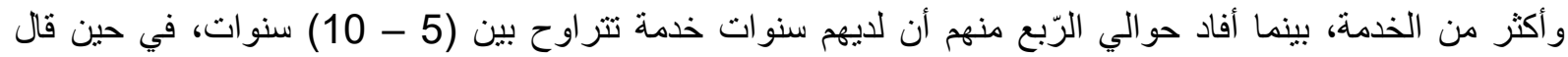

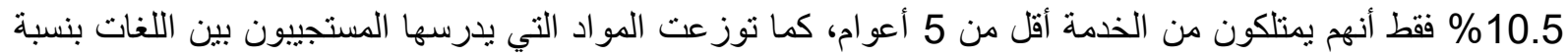
27.3\%، و العلوم بنسبة 20.3\% والرّياضيات بنسبة 17.5\% أما ما تبقى من الفئة المستهدفة كانو اليعلمون مواد

أداة الآرراسة: تم الرّجوع إلى الأدب النّربي من أجل اختبار فقرات الاستبانة، وقد نم استعمال استبانة الباحث (بني خلف،

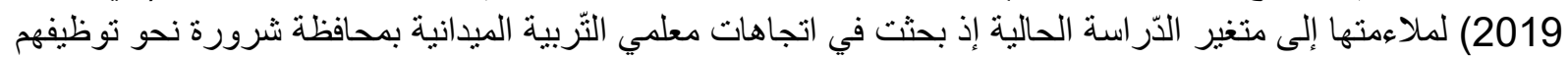

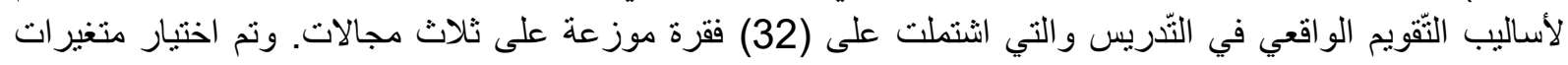

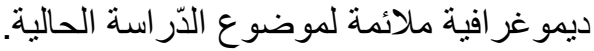

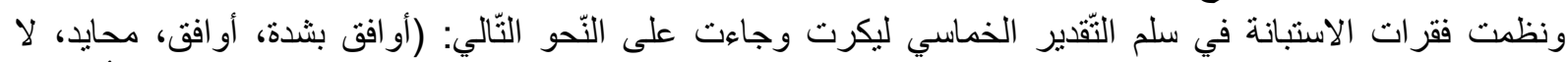

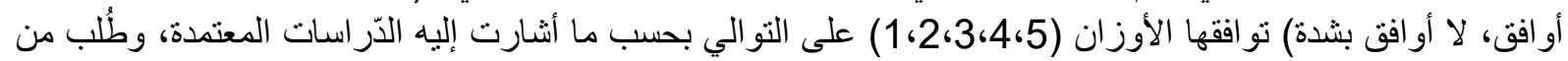

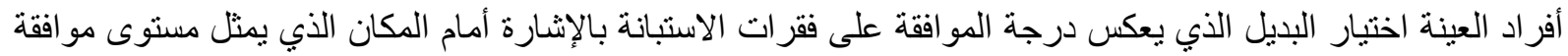

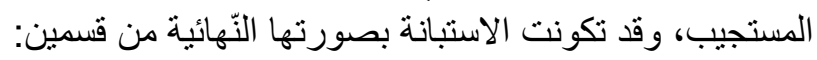

ـ القسم الأول: يشمل معلومات ديمو غر افية عن الفئة المستجيبة. ـ القسم الثاني: يشمل اتجاهات المعلمين نحو توظيف استر اتيجيات التّقويم البديل في التدريس و اشتنمل هذا القسم على ثناث

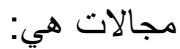
الأول: يفحص آراء المعلمين و اتجاهاتهم حول طبيعة التّقويم البديل ويحتوي على (8) فقرات. • الثاني: يفحص مو اقف المعلمين نحو توظيف أدوات التّقويم البديل في التدريس من ناحيتهم، ويحتوي على على (12)

• أما الثالث: يفحص آراء المعلمين حول توظيف أدوات التّقويم البديل في التدريس من ناحية الطّّلاب، ويحتوي على (12) فقرة. 


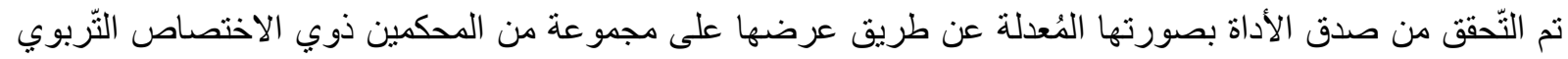

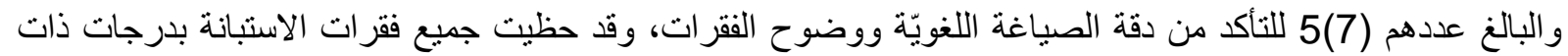

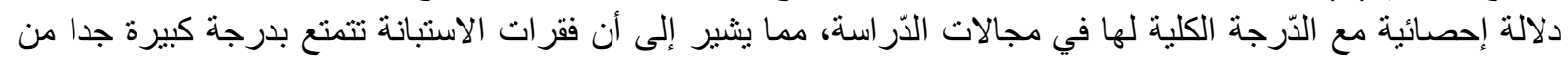

الصدق، و أنها صالحة لما لحس وضعت من أجل قياسه.

ثبات أداة الآر اسة:

نم التّققق من ثبات أداة الذّر اسة بعرضها على عينة استطلاعية من خارج العينة بلغ عددها (26) باستخدام معادلة الثبات

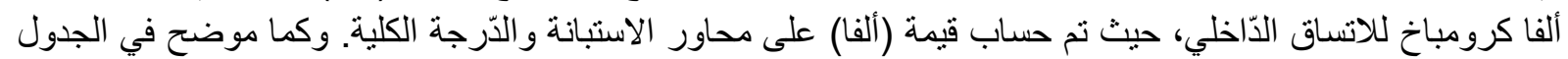

جدول (2) يبين معاملات الثبات على مستوى المجالات الكلي للادداة

\begin{tabular}{|c|c|c|c|}
\hline 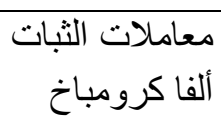 & عدد الفقرات & 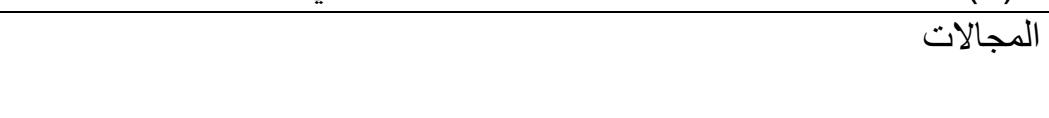 & \\
\hline 0.90 & 8 & الأول: آراء المعلمين و اتجاهاتهم حول طبيعة التّقويم البديل. & 1 \\
\hline 0.86 & 12 & الثاني: مو اقف المعلمين نحو توظيف استر اتيجيات التّقويم البديل من ناحيتهم & 2 \\
\hline 0.95 & 12 & الثالث: آر اء المعلمين نحو توظيف استر اتيجيات التّقويم البديل من ناحية الطُلاب & 3 \\
\hline 0.96 & 32 & قاستجابات المعلمين نحو توظباخ للمجالات الثلاثة الأولى: & \\
\hline
\end{tabular}

يتبين من الجدول (2) أن قيمة ألفا كرونباخ على المجال الأول الذي يتناول (آراء المعلمين واتجاهاتهم حول طبيعة التّقيم

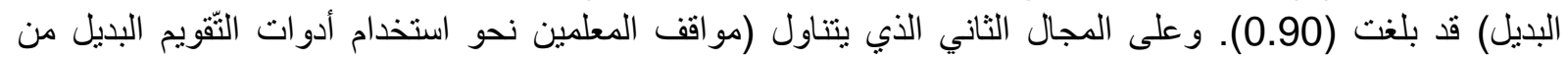

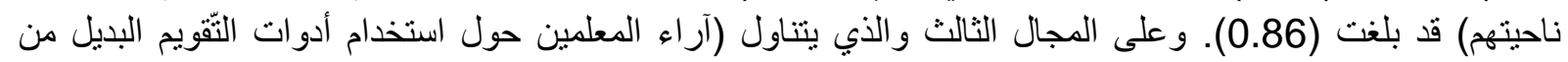

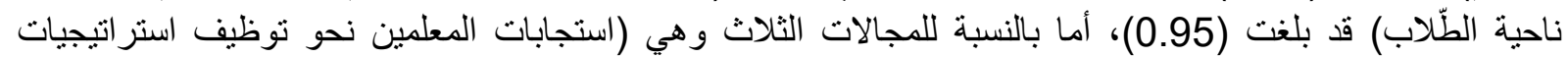

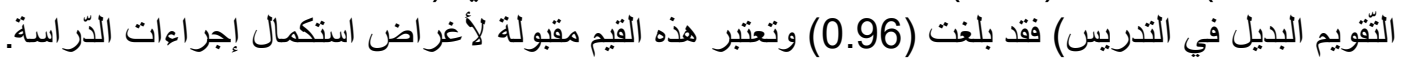

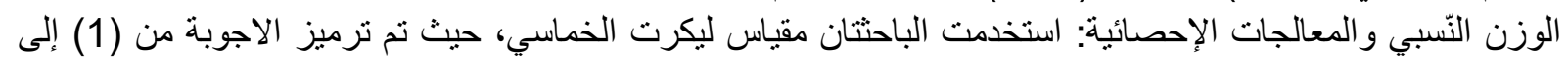

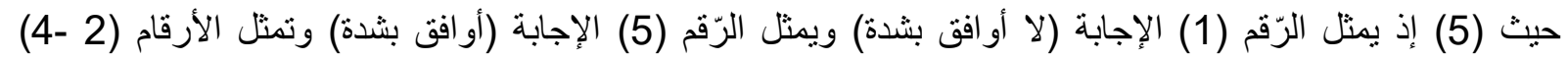

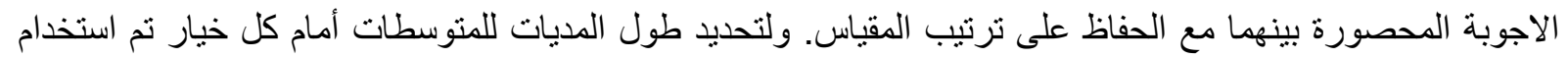

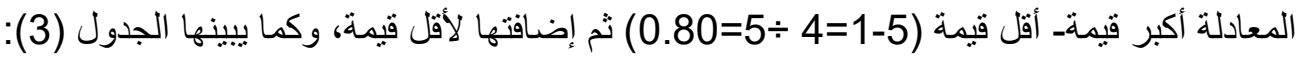

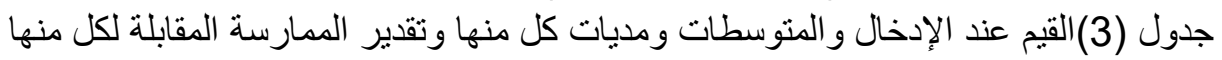

\begin{tabular}{|c|c|c|c|c|}
\hline تقدير الاستجابة & مديات المتوسطات & القيم عند الإدخال & خيار ات الإجابة & \\
\hline أو افق بشدة & $1.80-1$ & 1 & أو افق بشدة & 1 \\
\hline أو افق & $2.60-1.81$ & 2 & أو افق & 2 \\
\hline محايد & $3.40-2.61$ & 3 & محايد & 3 \\
\hline لا أو افق & $4.20-3.41$ & 4 & لا أو افق & 4 \\
\hline لا أوافق بشدة & $5-4.21$ & 5 & لا أو افق بشدة & 5 \\
\hline
\end{tabular}

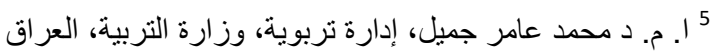

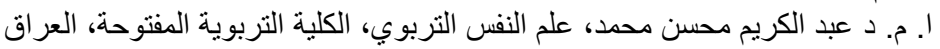

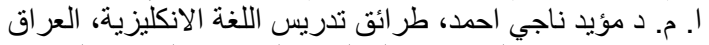

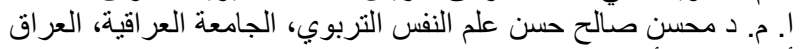

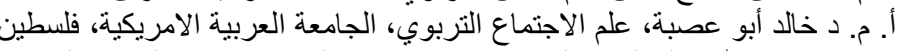

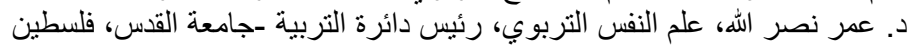

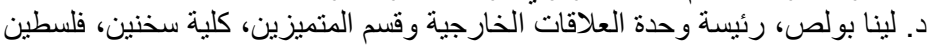


TTITUDES OF SECONDARY SCHOOL TEACHES IN EAST JERUSALEM TOWARDS MPLOYING ALTERNATIVE ASSESSMENT STRATEGIES IN TEACHING

\section{المعالجات الإحصائية المستخدمة في الآراسة:}

تم استعمال البرنامج (SPSS) للمعالجات الإحصائية ومنها: المتوسطات الحسابية والانحر افات المعيارية للإحصاء

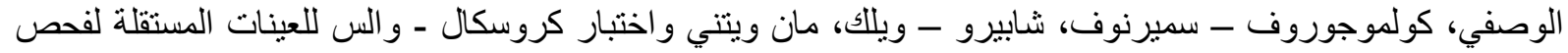
الفرضيات.

مناقشُة وتحليل نتائج الدّراسة:

بهدف الإجابة عن أسئلة الدّر اسة وفرضياتها استخرجت المتوسطات الحسابية والانحر افات المعيارية على وفق مجالات

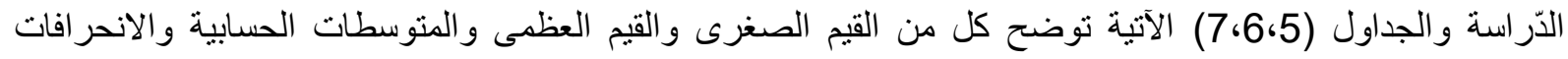

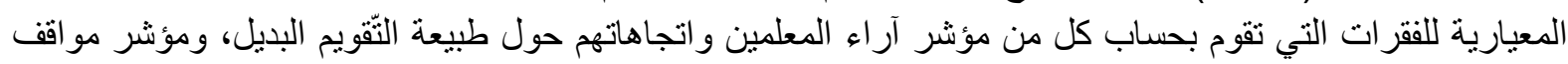

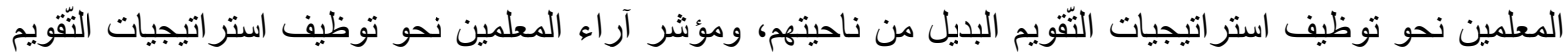
البديل من ناحية الطّلاب. ونم ترميز درجات القبول على هذه البنود وكما نوضح في في البون الجدول:

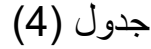
يبين المتوسطات الحسابية والانحر افات المعيارية لكل مجال من مجالات الدّر اسة.

\begin{tabular}{|c|c|c|c|c|}
\hline الالمعياري & الحسابي & عدد فقرات المجال & رقم المجال & الرّتبة \\
\hline 0.69 & 3.67 & 8 & 1 & 3 \\
\hline 0.54 & 3.85 & 12 & 2 & 1 \\
\hline 0.77 & 3.69 & 12 & 3 & 2 \\
\hline
\end{tabular}

يتضح من الجدول (4) أنّ المتوسطات الحسابية والانحرافات المعيارية لمجالات المقياس حيث تجاوزت متوسطات

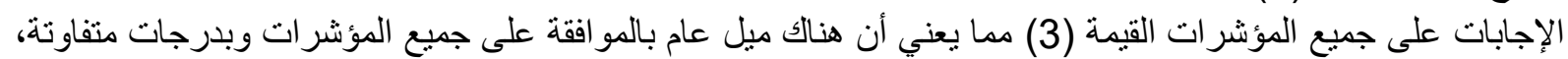

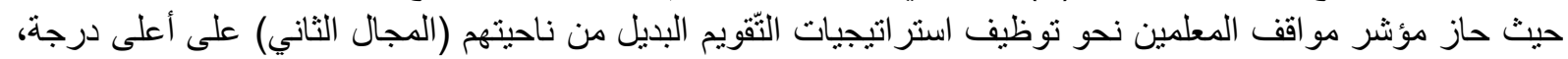

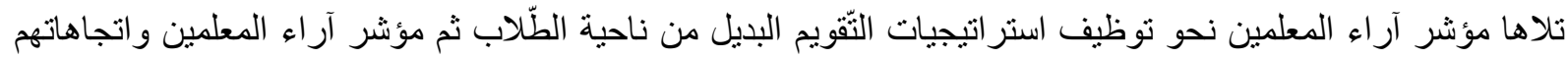
حول طبيعة التّقويم البديل بدرجة مو افتقة

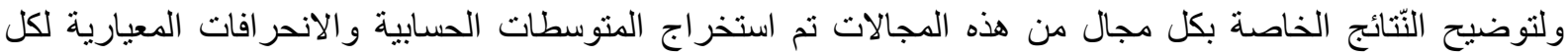

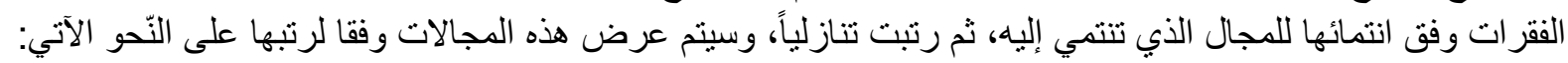

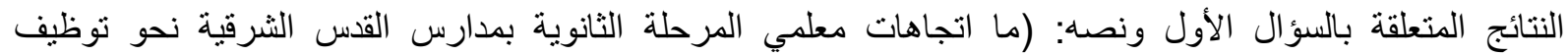

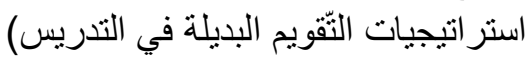

أولا: آراء المعلمين واتجاهاتهم حول طبيعة التّويم البديل وكما موضح في الجدول (5)

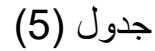
يبين المتوسطات الحسابية والانحر افات المعيارية لإجابات العينة على الفقرات المتعلقة بآراء المعلمين و اتجاهاتهم حول

\begin{tabular}{|c|c|c|c|c|c|}
\hline 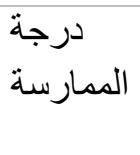 & 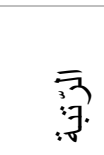 & 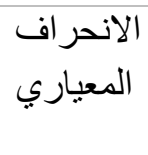 & المتوسط & الفقرات & الرّقم \\
\hline عالية & 1 & 0.84 & 3.86 & 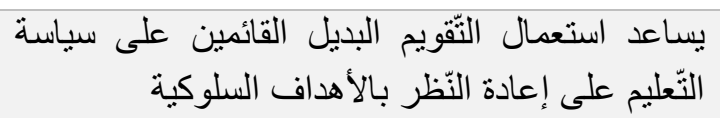 & 4 \\
\hline عالية & 2 & 0.84 & 3.82 & التّنقويم البديل بيتعمل استر اتيجيات مستقبلية تلائم & 7 \\
\hline عالية & 3 & 0.92 & 3.73 & التعليم والتعلم البديل يُتيح الفرصة الكاملة لتكامل عمليتي & 8 \\
\hline
\end{tabular}




\begin{tabular}{|c|c|c|c|c|c|}
\hline عالية & 4 & 0.88 & 3.69 & التّقويم البديل يُسهح في الرّبط بين المدرسة و الأسرة & 6 \\
\hline 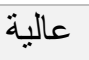 & 5 & 0.85 & 3.63 & التّقويم البديل يركز على المهارات الحياتية للطبلة & 1 \\
\hline عالية & 6 & 1.01 & 3.62 & التّلّتيدية البديل يعالج القصور الحاصل في الاختبار & 5 \\
\hline عالية & 7 & 0.83 & 3.57 & التّقويم البديل يركّز على العمليات ونواتج التّعلم & 3 \\
\hline عالية & 8 & 0.98 & 3.44 & 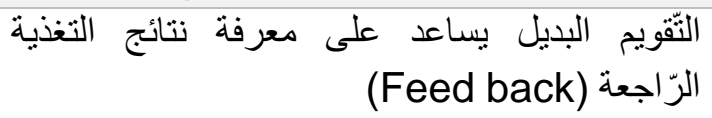 & 2 \\
\hline 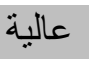 & & 0.69 & 3.67 & آر اء المعلمين و اتجاهاتهم حول طبيعة التّقويم البديل & \\
\hline
\end{tabular}

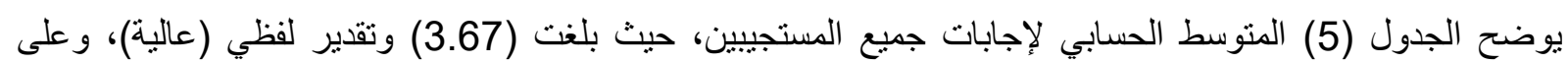

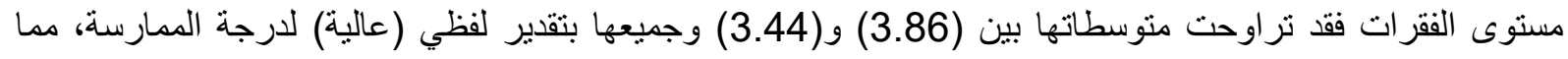

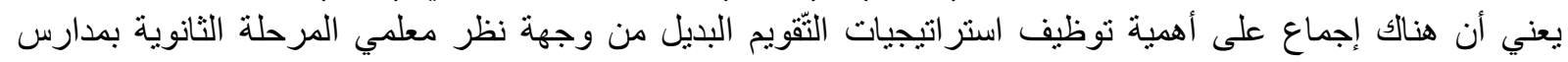
القس الثرقية بدرجة عالية.

ثانياًـ مواقف المعلمين نحو توظيف استراتيجيات التَّقويم البديل من وجهة نظرهم وكما موضح في الجدول:

جدول (6)

ييين الكتوسطات الحسابية والانحر افات المعيارية لإجابات العينة على الفقرات المتعلقة بمو اقف المعلمين نحو توظيف استر اتيجيات التقويم البديل مرتبة ترتيياً تنتازلياً

\begin{tabular}{|c|c|c|c|c|c|}
\hline 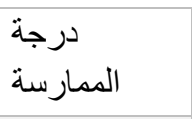 & الرّتبة & 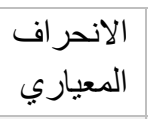 & الوسط الحسب & 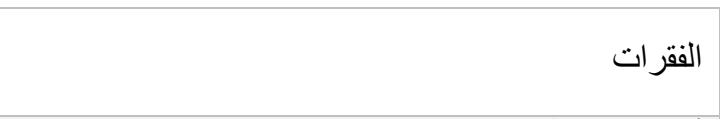 & الرّقم \\
\hline 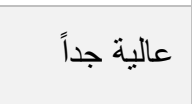 & 1 & 0.67 & 4.26 & أن تطبيق التّقويم البديل بحاجة إلىى إعادة النّظر بمحتوى الحين & 5 \\
\hline 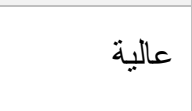 & 2 & 0.76 & 4.03 & الملائمة للموقف البديل يسّاعدني في اختيار الوسائل التّليمية & 6 \\
\hline 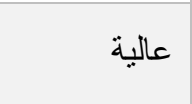 & 3 & 0.79 & 4.03 & إنّ تطبيق التّقيم البديل بحاجة إلى إعادة النّظر بعدد & 8 \\
\hline 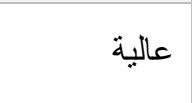 & 4 & 0.75 & 3.98 & ألتّويم البديل بحاجة إلى تدريب مستمر في توظيف أساليب & 1 \\
\hline 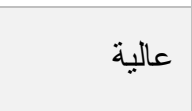 & 5 & 0.84 & 3.97 & الملائمة للموقف البديل بيساعدني في تتويع أساليب التّريس & 10 \\
\hline 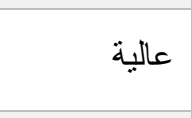 & 6 & 0.85 & 3.92 & 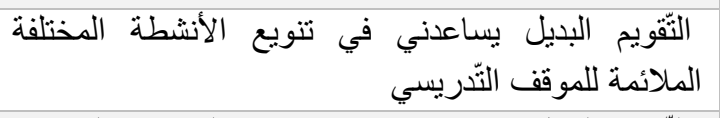 & 7 \\
\hline 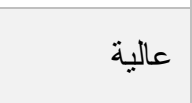 & 7 & 0.89 & 3.77 & 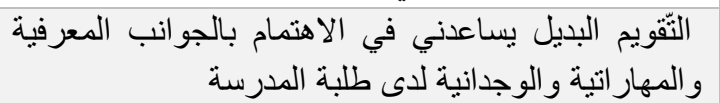 & 9 \\
\hline عالية & 8 & 0.93 & 3.76 & التقّيم البديل بضيف عبئا وجهدا اضافيين & 3 \\
\hline 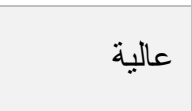 & 9 & 0.90 & 3.70 & المتباينة البّميم البديل يزودوني بمعلومات حول قدرات الطّلبة & 2 \\
\hline 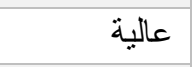 & 10 & 0.95 & 3.60 & التّقويم البديل بساعدني على تأهيل نفسي تربويا & 12 \\
\hline 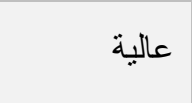 & 11 & 0.93 & 3.59 & كمعلم التّويم البديل يساعد في تقيم تغذية راجعة عن أدائي & 4 \\
\hline عالية & 12 & 0.96 & 3.57 & التّقويم البديل يساعد أولياء الأمور في متابعة تقدم أبنائهم & 11 \\
\hline عالية & & 0.54 & 3.85 & من وجهة نظرهم المعين نحو توظيف استراتيجيات التّقويم البديل & \\
\hline
\end{tabular}


نم عمل التّرميز المستخدم في مواقف المعلمين نحو توظيف استر اتيجيات التّقويم البديل من ناحيتهم وكانت النّائج كما في

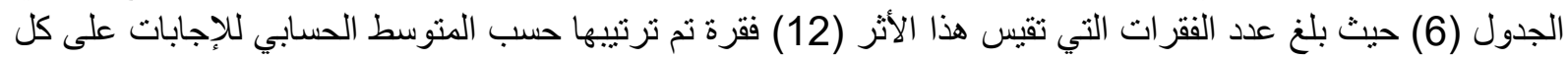

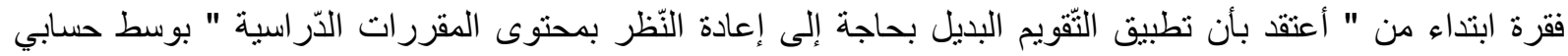

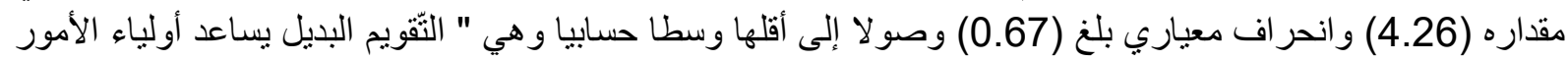

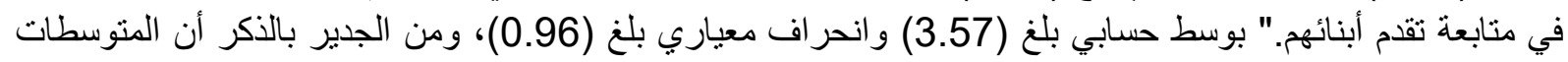

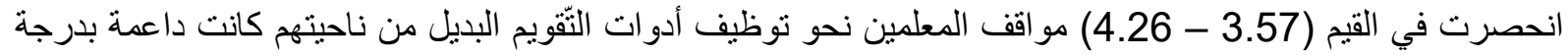

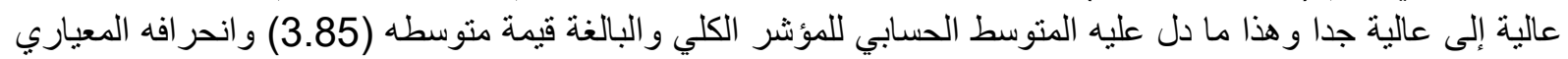

ثالثاً آراء المعلمين نحو توظيف أدوات التّقويم البديل من ناحية الظّلاب كما موضح في الجدول (7):

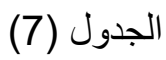

\begin{tabular}{|c|c|c|c|c|c|}
\hline الممارسد & 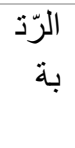 & الانحر افياري & الحسابي & 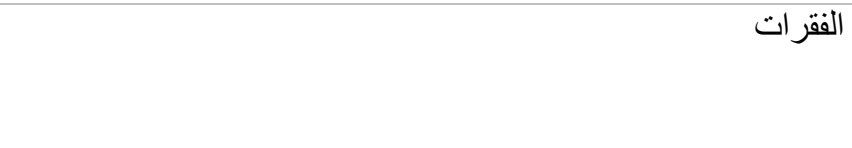 & الرّقم \\
\hline عالية & 1 & 0.85 & 3.88 & التقّويم البديل يسهم في نهيئة الطّلبة لتعلم الموضو عات الجديدة & 10 \\
\hline عالية & 2 & 0.86 & 3.83 & التقويم البديل يتيح فرصة التّقيم الذاتي للطلبة & 9 \\
\hline عالية & 3 & 0.97 & 3.78 & هو جديد البّديل يشجع الطَّلبة على حب الابتكار و الاطلاع على كل ما & 3 \\
\hline عالية & 4 & 0.84 & 3.78 & التّقيم البديل يساعد في تقديم تغذية راجعة للطلبة & 8 \\
\hline عالية & 5 & 0.93 & 3.73 & التّويم البديل ينمي المهار ات العقلية العليا عند الطُلبة & 4 \\
\hline عالية & 6 & 0.92 & 3.71 & التّقويم البديل ينمي الثقة بالنفس لدى الطُّلبة & 11 \\
\hline عالية & 7 & 0.96 & 3.67 & التّقويم البديل يجعل الطُّلبة ينغمسون في مو اقف حقيقة ذات معنى & 12 \\
\hline عالية & 8 & 1.07 & 3.64 & التّقويم البديل يشجع روح التّنافس بين الطَلبة أنفسهح & 1 \\
\hline عالية & 9 & 1.03 & 3.62 & التّويم البديل ينمي مهار ات الاتصال الكتابية و الثفوية عند الطلّبة & 6 \\
\hline 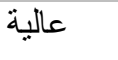 & 10 & 1.00 & 3.61 & التّقويم البديل يساهم في رفع المستوى التّحصيلي للطلبة & 2 \\
\hline عالية & 11 & 0.95 & 3.59 & التّقويم البديل ينمي لدى الطُّلبة علاقات اجنماعية طيبة & 7 \\
\hline عالية & 12 & 1.02 & 3.49 & التّويم البديل يساعد في تقويم الطلّبة بموضو عية أدق & 5 \\
\hline عالية & & 0.77 & 3.69 & آلطّاء المعلمين نحو توظيف استراتيجيات التّويم البديل من ناحية & \\
\hline عالية & & 0.60 & 3.74 & 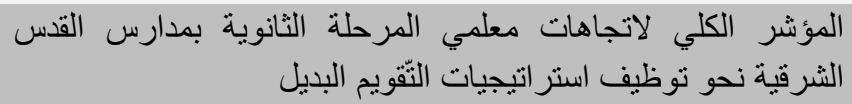 & \\
\hline
\end{tabular}

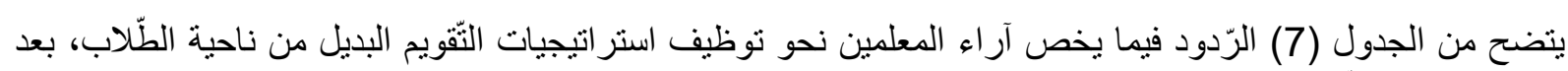

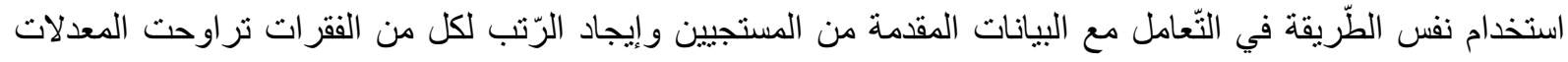

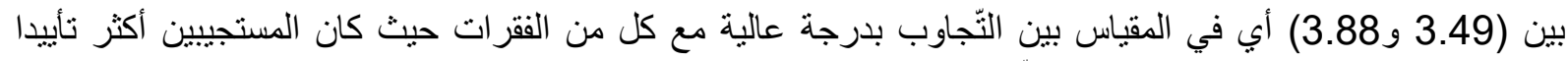

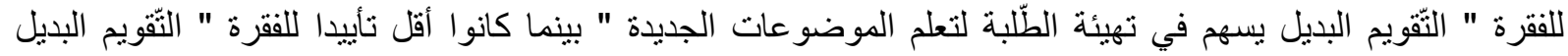


يساعد في تقويم الظّلبة بموضو عية أدق." مع التّاكيد على أن المستجييين و افقوا على هذه الفقرة بدرجة عالية وهذا ما دل

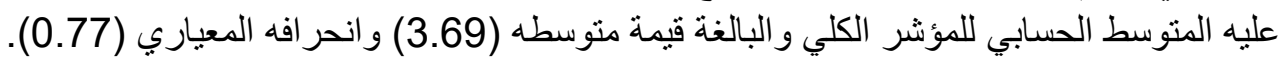

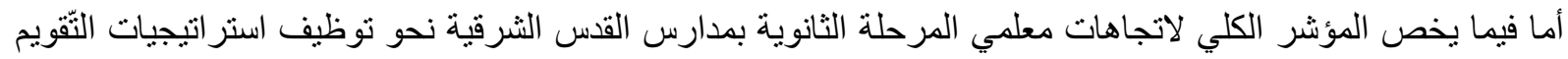

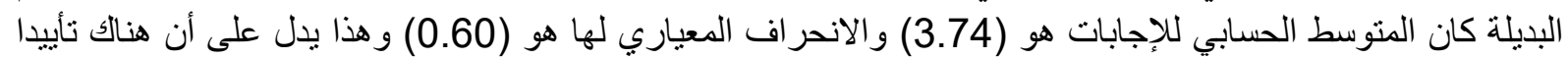

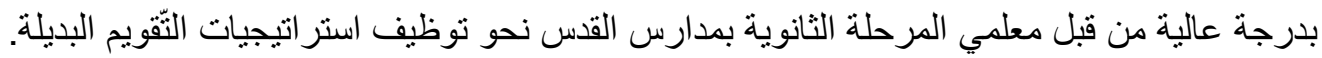

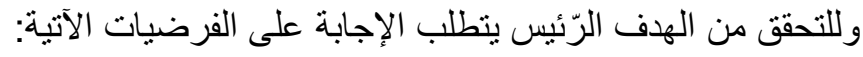

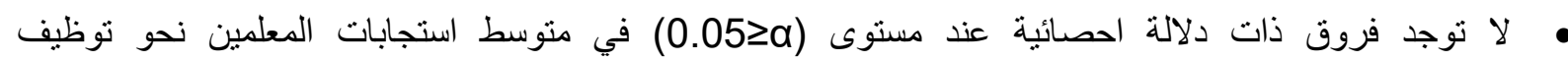

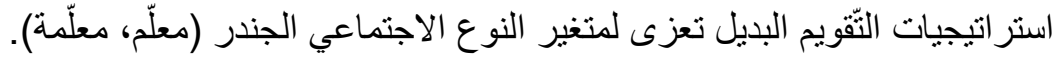

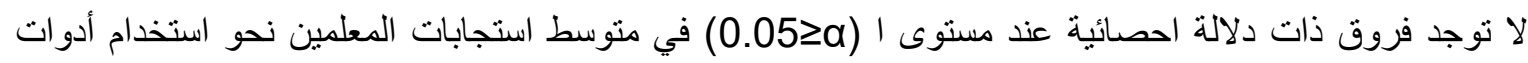

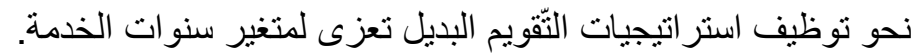

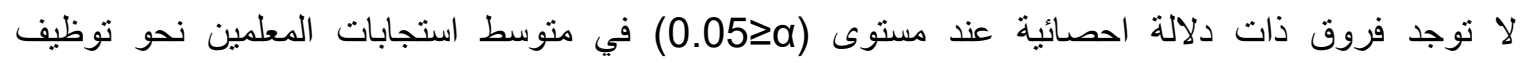
استر اتيجيات التّويم البديل تعزى لمتغير المات دلادة التّعليمية.

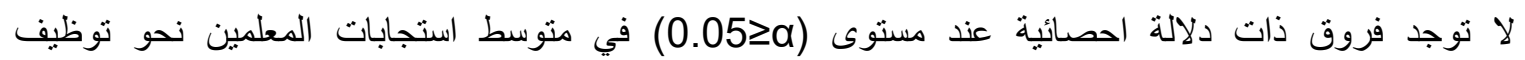

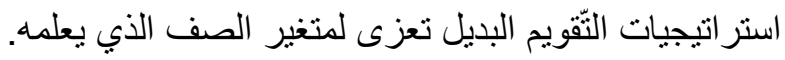

للتمكن من اختبار الفرضيات تم حساب متغير جديد وهو عبارة عن معدل المتغيرات الثلاثة التي تم حسابها سابقا وهي: ـ أو لا: آراء المعلمين و اتجاهاتهم حول طبيعة التّقويم البديل.

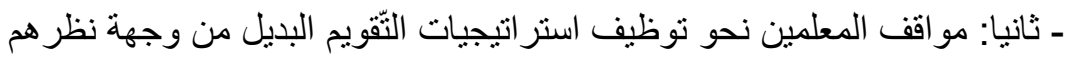

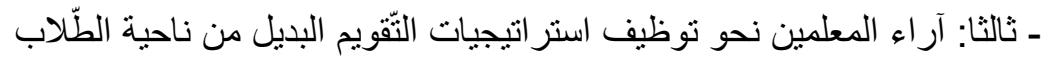

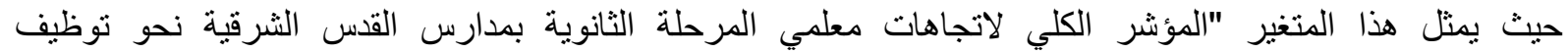

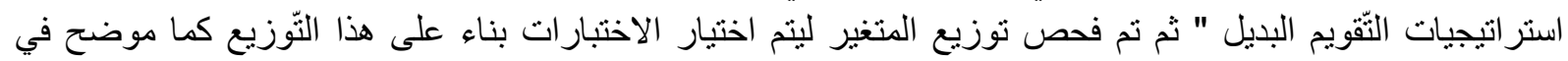

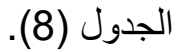
جدول (8) يبين اختبار التّوزيع الطّبيعي للمتغيرات التّابعة

\begin{tabular}{|c|c|c|c|c|c|c|}
\hline & & & & & & \multirow[t]{4}{*}{ اختبار النّوزيع الطُبيعي } \\
\hline \multicolumn{3}{|r|}{ شابيرو - ويلك } & \multicolumn{3}{|c|}{ كولموجوروف - سميرنوف } & \\
\hline القيمة & درجة & \multirow[t]{2}{*}{ قيمة الاختبار } & 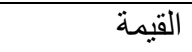 & درجة & \multirow[t]{2}{*}{ قيمة الاختبار } & \\
\hline الاحتمالية & 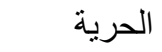 & & الاحتمالية & 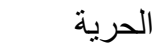 & & \\
\hline .000 & 143 & .936 & .000 & 143 & .122 & 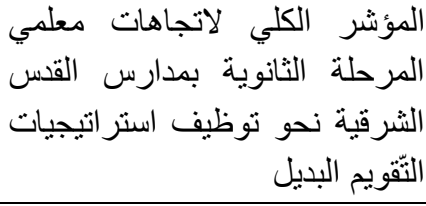 \\
\hline & & & & & & aتعديل ليليفورس للقيمة الاحتمالية \\
\hline
\end{tabular}

بالرّجوع إلى الجدول (8) نجد أن القيمة الاحتمالية لاختبار كولموجوروف أقل من

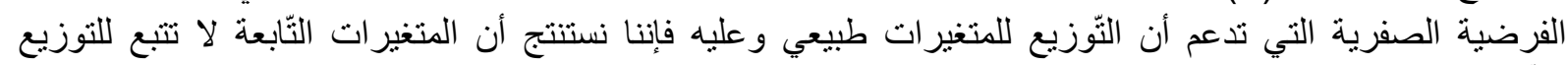

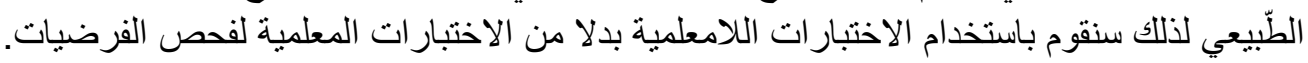

نتائج الفرضية الرَئيسة: الجدول (9) نتائج الاختبار ات اللادمعلية (اختبار مان ويتني واختبار كروسكال - و الس) لفحص وجود فروق ذات دلالة

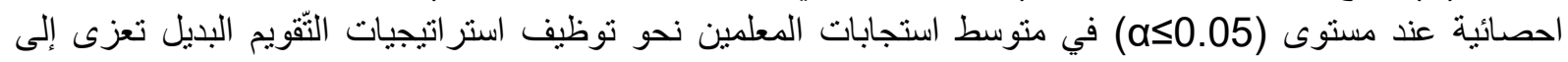

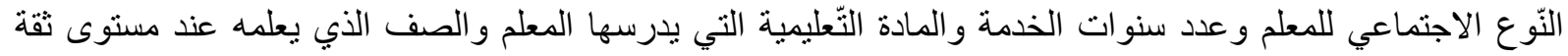




\begin{tabular}{|c|c|c|c|c|c|c|}
\hline & & & & & \multicolumn{2}{|c|}{ ملخص اختبار الفرضيات } \\
\hline & الاحتمالية & دالحرية & قاخمة & الاختبار & الفرضية الصفرية & \\
\hline 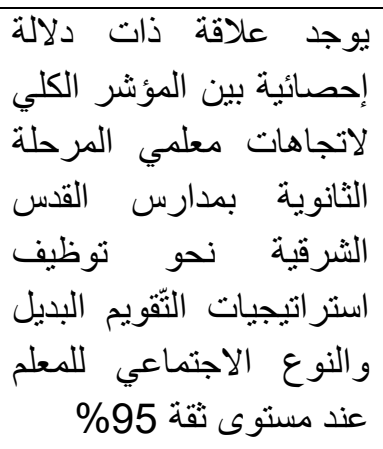 & $<0.001$ & & 1465.0 & اللعبنتات & 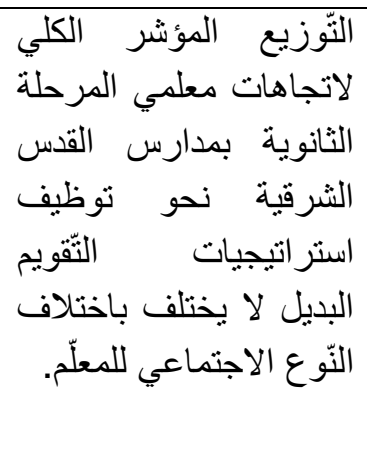 & 1 \\
\hline 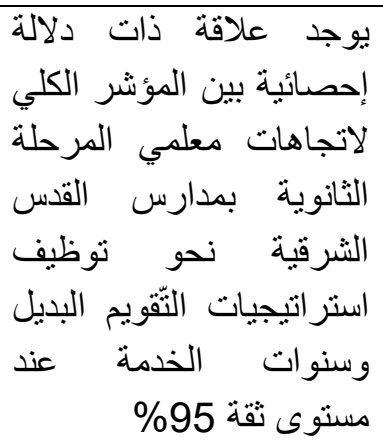 & $<0.001$ & 2 & 31.586 & - كروسكال & 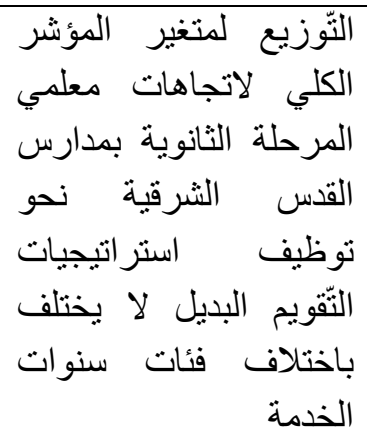 & 2 \\
\hline 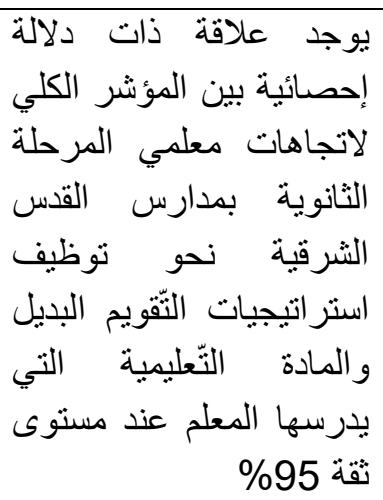 & 0.018 & 3 & 1.096 & - اختبار & 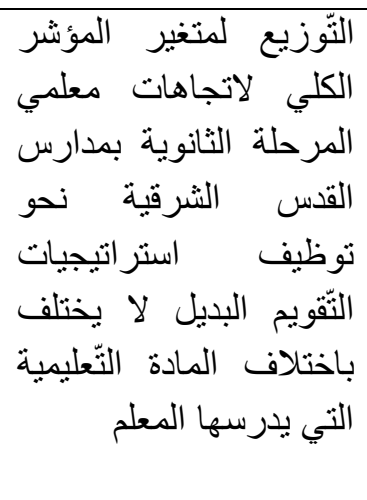 & 3 \\
\hline 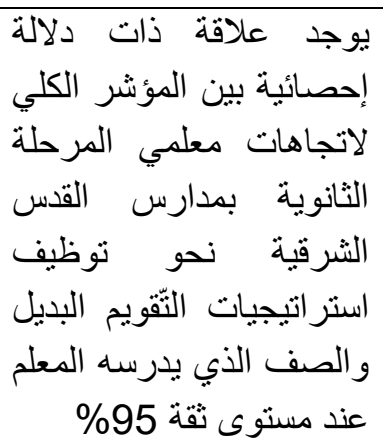 & 0.003 & 2 & 11.946 & - كروسكال & 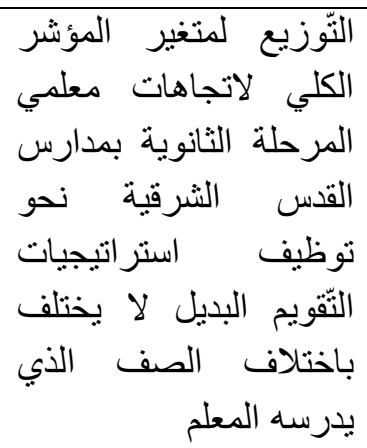 & 4 \\
\hline
\end{tabular}

يتبين من الجدول(9) نتائج فحص الفرضية الصفرية الأولى و الفرضيات الصفرية المتفرعة منها وهي "لا يوجد علاقة

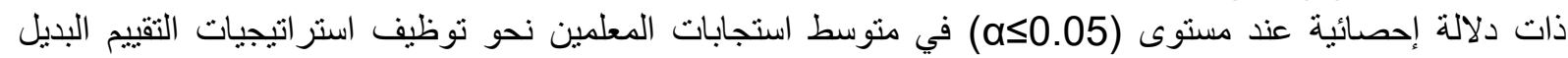

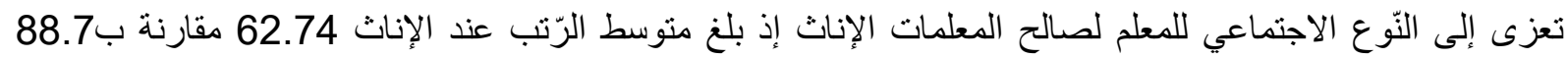

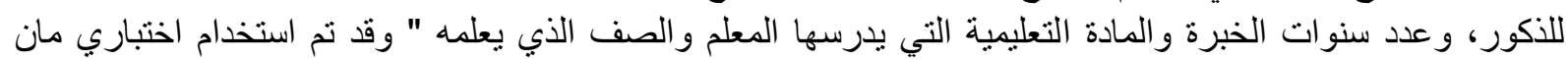

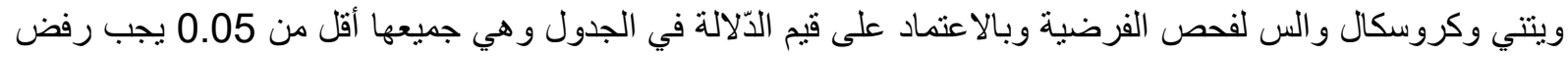
الفرضية الصفرية الرّئيسة و الفرضيات المتفر عة منها و عليه فإننا سنقوم بالاستنتاج أنه: 
"توجد فروق ذات دلالة احصائية عند مستوى (as0.05) في منوسط استجابات المعلمين نحو توظيف استر اتيجيات

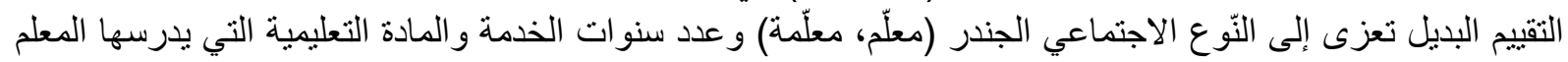

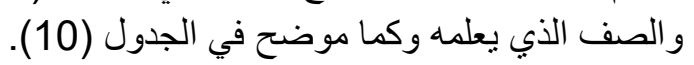

الجدول (10)

يبين المقارنات الثنائية بين متوسط الرّتب للمتغير ات التابعة للفئات المختلفة من المتغيرات المستقلة

\begin{tabular}{|c|c|c|c|c|c|c|}
\hline العينة 2 & رتب & المعيارية & الاختبار & العينة 1 - العينة 2 & المتنقل & المتغير التابع \\
\hline 92.93 & 58.5 & .000 & 34.429 & و أقل منسنوات فأكثر-أكبر من 5 & \multirow{3}{*}{ سنوات } & \multirow{3}{*}{ وآراء التقاهيبم لمعلمين حول } \\
\hline 106.87 & 58.5 & .000 & 48.367 & سنوات 10نوات فأكثر -أقل من 5 & & \\
\hline - & - & .826 & 13.938 & أكبر من 5 سنو وأقل من-10 أقل & & \\
\hline- & - & 1.000 & 11.180 & أخرى-الرياضيات & \multirow{6}{*}{ التي } & \multirow{6}{*}{ آراتجاهاتهم التمعيم حول البديل } \\
\hline- & - & .226 & 18.390 & أخرى-لغات & & \\
\hline 88.66 & 59.02 & .013 & 29.635 & أخرى-العلوم & & \\
\hline- & - & 1.000 & 7.210 & الرياضيات-لغات & & \\
\hline- & - & .614 & 18.455 & الرياضيات_العلوم & & \\
\hline- & - & 1.000 & -11.245 & لغات-العلوم & & \\
\hline 79.96 & 59.62 & .041 & 20.345 & صف الثاني عشر-صف الحادي & \multirow{3}{*}{ الـعلي } & \multirow{3}{*}{ آراء آتجاهاتهم حول لمعلين } \\
\hline 86.96 & 59.62 & .005 & 27.339 & صف الثاني عثر-صف العانشر & & \\
\hline - & - & 1.000 & 6.995 & صف الحانشر & & \\
\hline
\end{tabular}

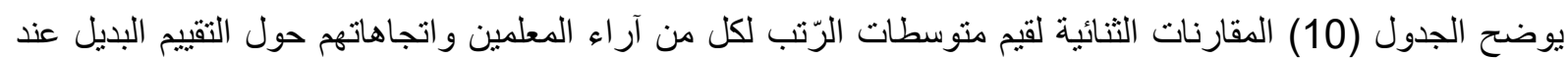

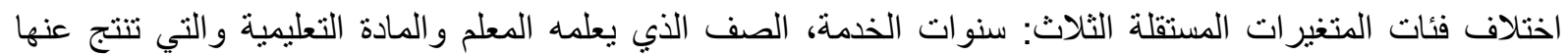

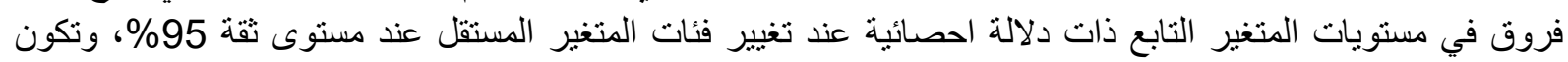
هذه الفروق لصالح الفئة ذات معدل الرّتب الأقل وبناء التاء عليه:

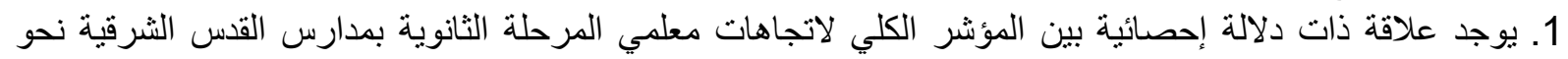

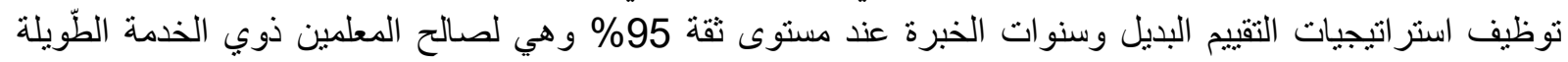

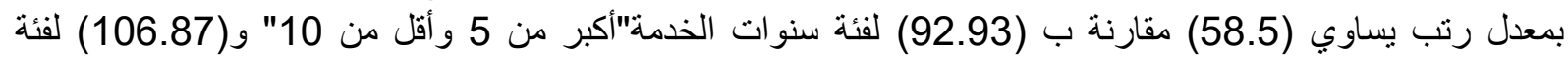

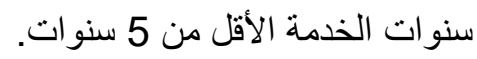
2. يوجد علاقة ذات دلالة إحصائية بين المؤشر الكلي لاتجاهات معلمي المرحلة الثانوية بمدارس القدس الثرقية نحو

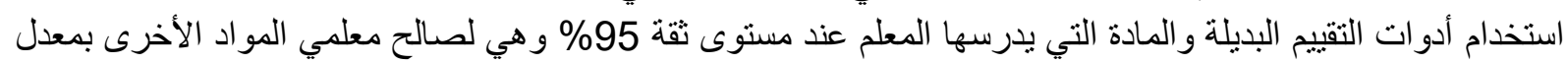

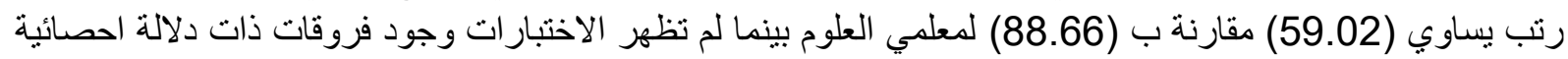

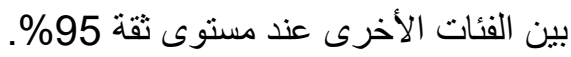

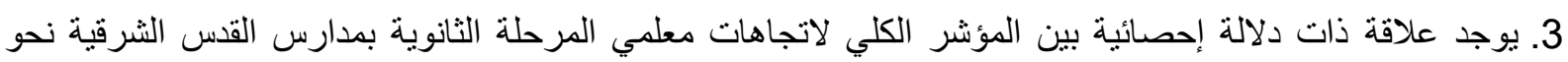

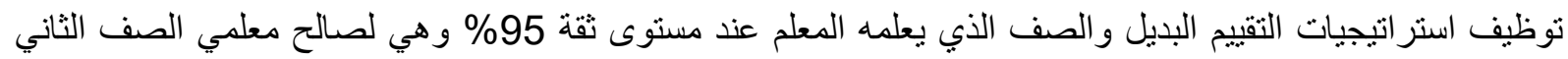

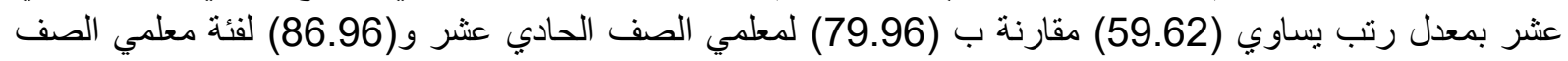
العاثر بينما لم تظهر الاختبار ات وجود فروقات ذات دلالة احصائية بين الفئات الأخرى عند مستوى ثقية 
TTITUDES OF SECONDARY SCHOOL TEACHES IN EAST JERUSALEM TOWARDS

MPLOYING ALTERNATIVE ASSESSMENT STRATEGIES IN TEACHING

مناقشة النّائج:

يتناول هذا الفصل مناقثنة النتّائج التي توصلت إليها الباحثتان عن طريق التّحليل الإحصائي لأسئلة الدّراسة وفرضياتها،

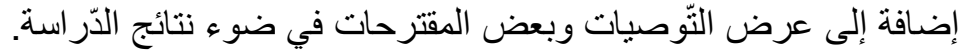

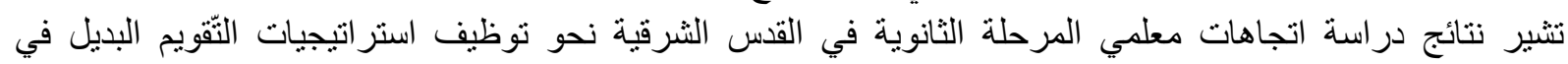
التدريس إلى النّائج الآتية:

مناقشة النّتائج المتعلقة بالسؤال الرَّئيس:

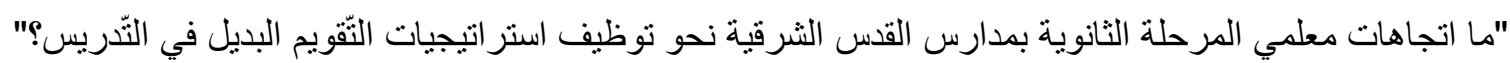

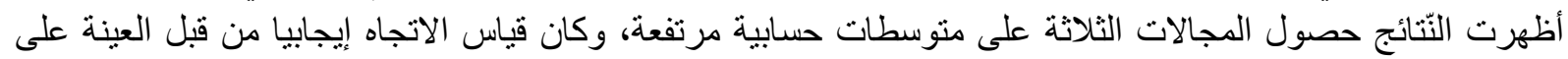

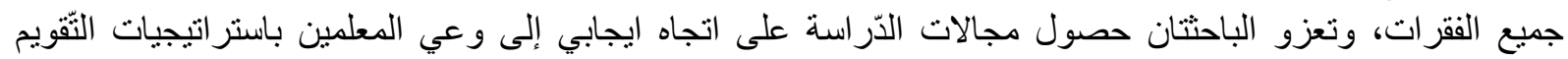

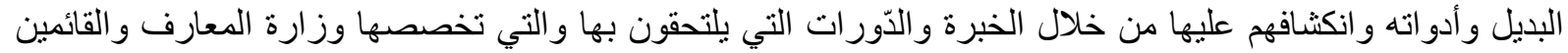

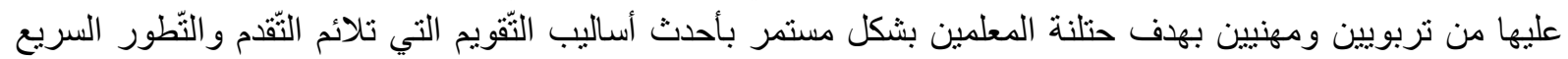

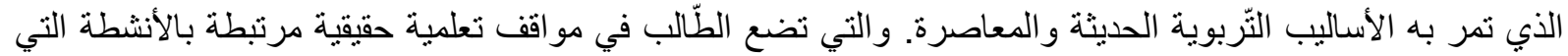

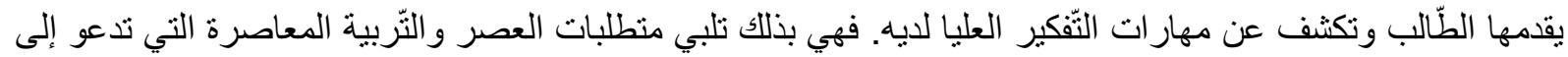
تربية إبداعية حوارية وليس تربية تلقين تينيه بنكية.

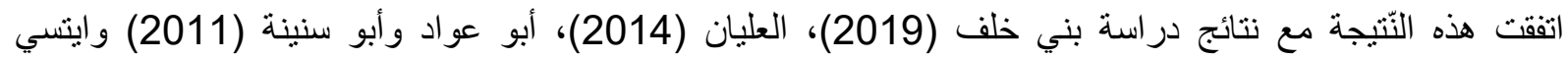

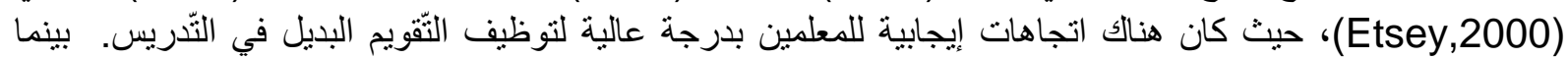
حصلت دراسة المقابلة والعواودة (2016) على ان اتجاهات المعلمين نحو نوظيف التّقيم البديل متوسطة. وخالفت

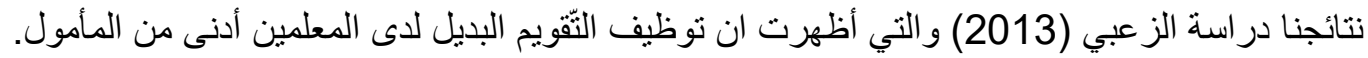

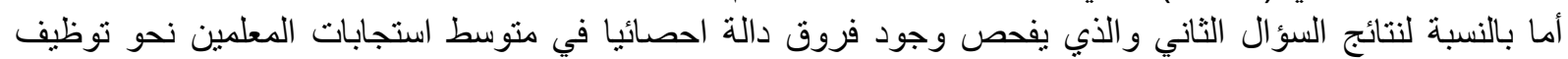

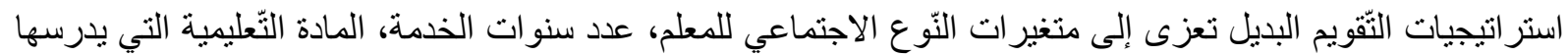

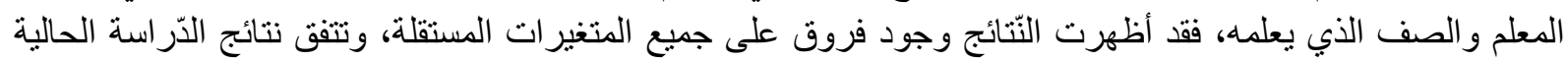

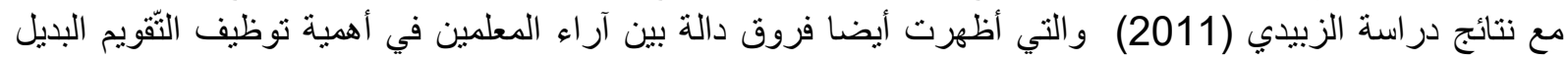

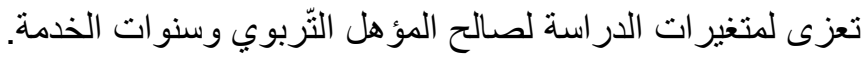

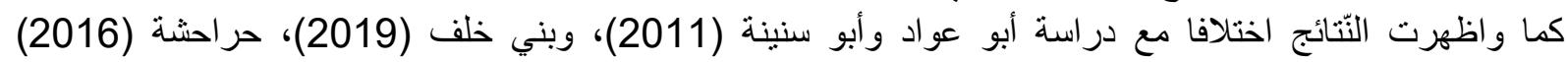
و المقابلة والعواودة (2016) من حيث عدم وجود فروق ذات دلالة إحصائية تعزى لكل من متغير المادة الذّراسية وسنوات الخدمة.

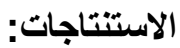

إن اتجاهات معلمي المرحلة الثنانوية بالقدس الثرقية نحو توظيف استر اتيجيات الثّقويم البديل كانت إيجابية وبدرجة كبيرة،

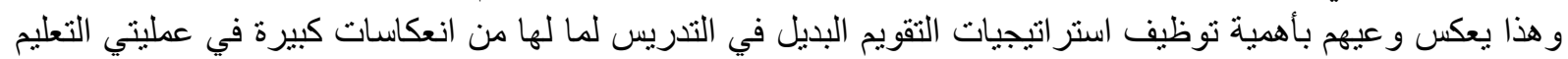

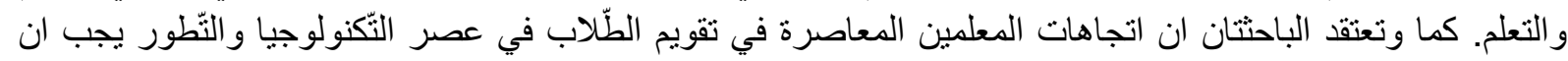

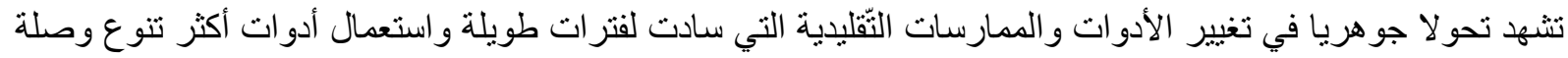

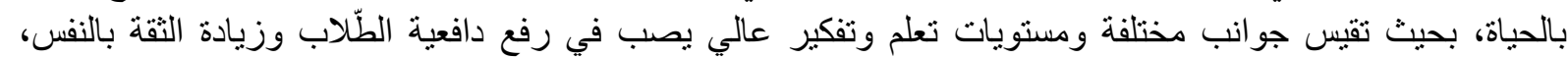

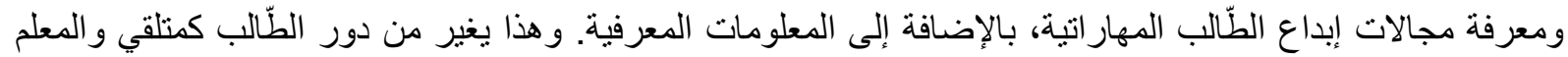

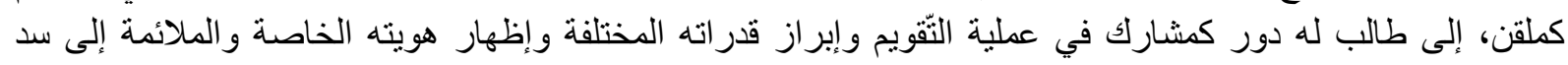

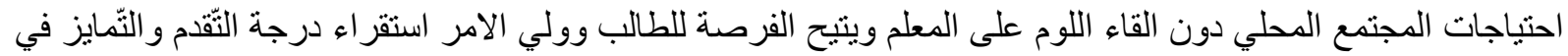

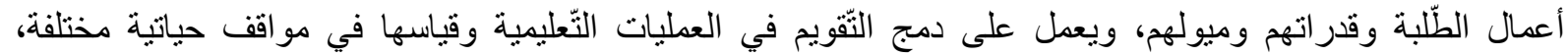

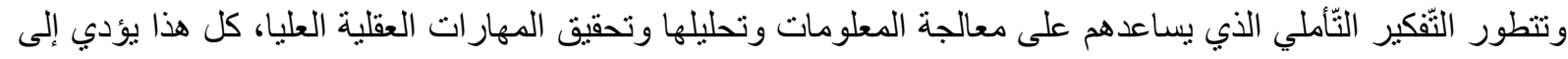

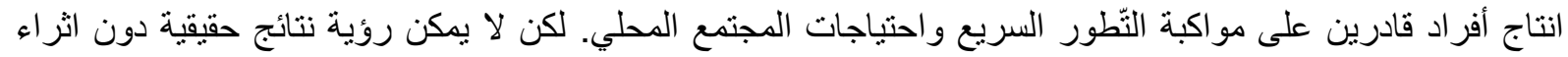

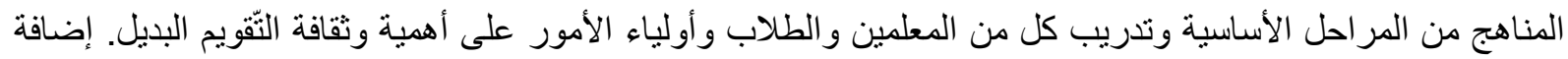


إلى ذلك العمل على تغيير معايير قبول الجامعات بطريقة تلائم الطّّرق الجديدة في التّقويم، والحث على البحث العلمي

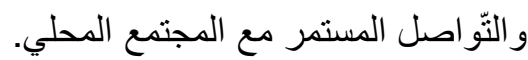

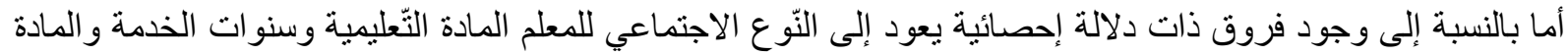

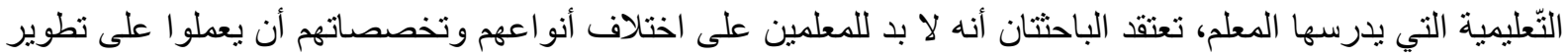

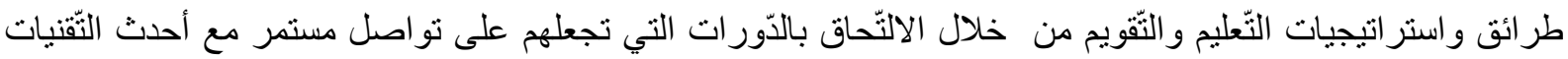

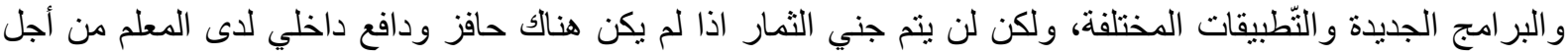

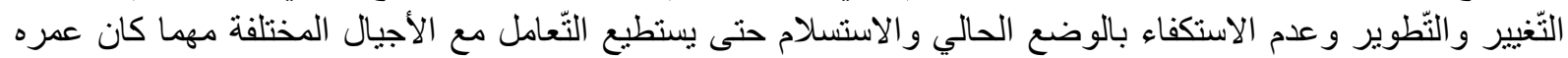

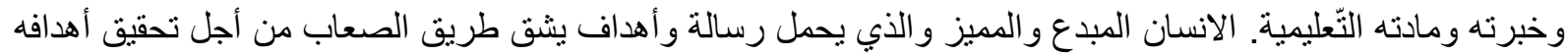

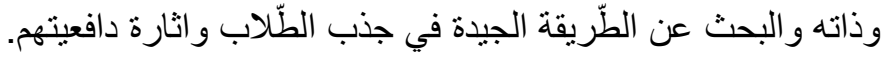

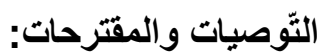

بناء على نتائج الذّر اسة توصي الباحثنان وتقترحان ما يلي:

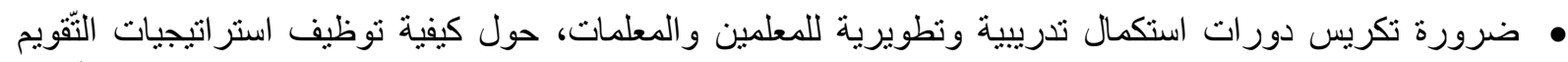

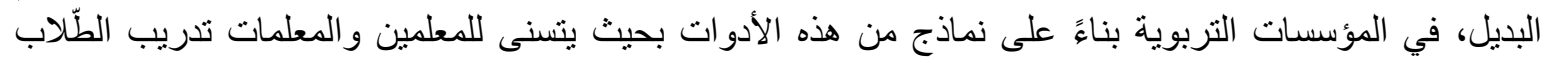

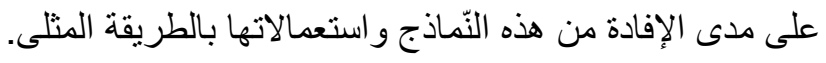

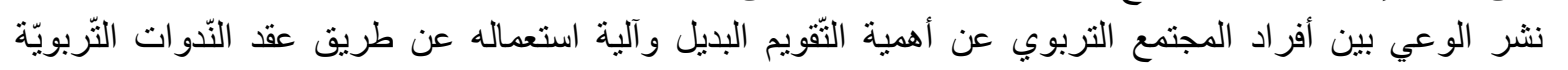
وورش العمل التي تقيمها وزارة المعارف. لقدئ.

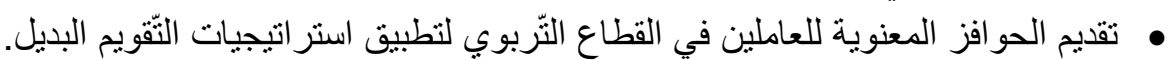

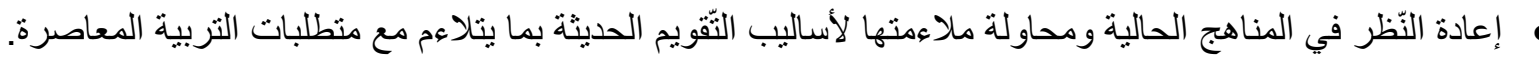

\section{مقترحات لار اسات مستقبلية}

• عمل دراسات تفحص في أدوات التّويم البديل ومعرفة الإشكاليات التي تحد من تطبيقها في المؤسسات التّربويّة.

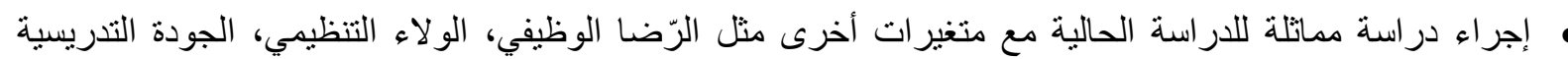
ونتائجها على توظيف التقويم البديل في التدريس.

\section{قائمة المراجع قائمة المراجع العربية:}

أكرم الزبيدي. (2011). و اقع استخدامأساليب التقويم البديل لاى معلمي ومعلمات العلوم بمحافظة الليث. مكتبة المنهل الألكترونية.

آمال الزعبي. (2013). درجة معرفة وممارسة معلّمي الرياضيات لإستر اتيجيات التقويم الو اقعي و لإدو اته. مجلة الجامعة

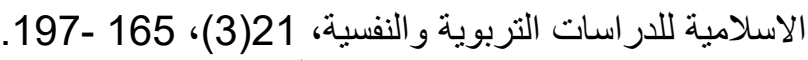

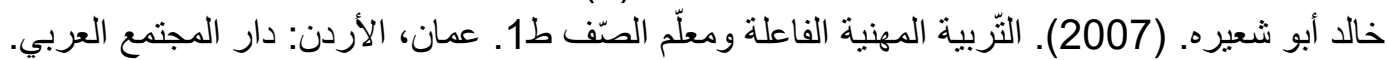

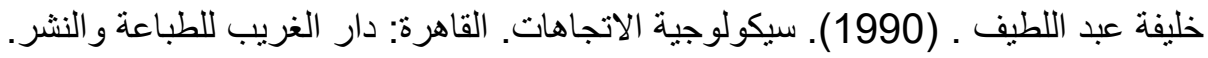

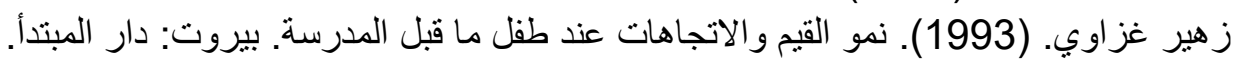

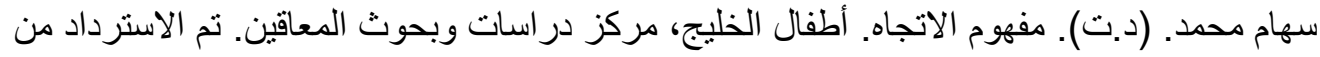
http://www.gulfkids.com/pdf/Etegah_S.pdf

صلاح الدّين علام. (2004). التّقويم الثّربوي البديل _ اسسه النّّرية النظرية و المنهجية وتطبيقاته الميدانية. القاهرة: دار

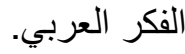

عبد الحكيم مهيدات، و إير اهيم المحاسنة ـ (2009). (2006). التقويم الواقعي. عمان: دار جرير للنشر والتوزيع.

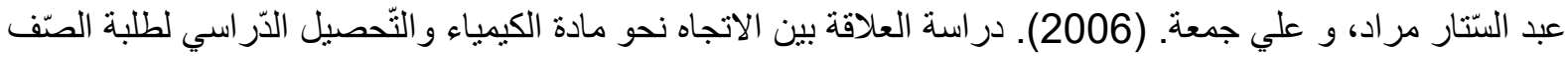

السّادس العلمي. كلية التّربية، جامعة ديالا. 
فربال أبو عوّاد، و عودة أبو سنينة. (2011). معتقدات معلّمي الدّراسات الاجتماعية حول التّقويم البديل في المراحل

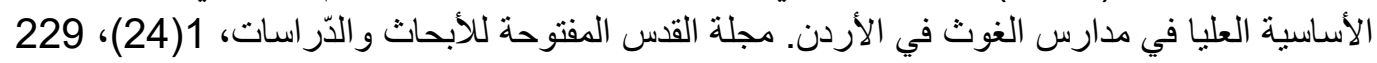

.266-

فريد أبو زينة. (2001). تطوير أدوات قياس تحصيل الطلبة في مادة الرياضيّات. مجلة مركز البحوث التربويّة، جامعة

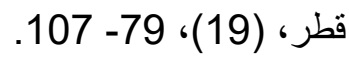

فهد العليان. (2014). اتجاهات معلّمي الرياضيات بالمرحلة المتوسطة نحو استخدام التقويم البديل في تعلّمّ الرياضيات.

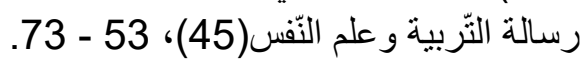

كوثر حر احشة. (2016). و اقع استخدام معلّمي العلوم لإستر اتيجيات التّقويم البديل و أدو اته في المرحلة الأساسية العليا في

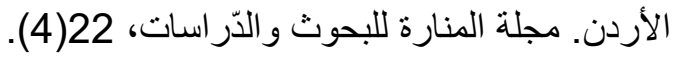

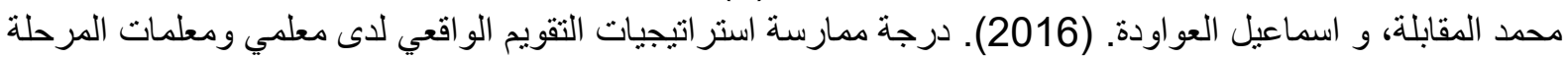

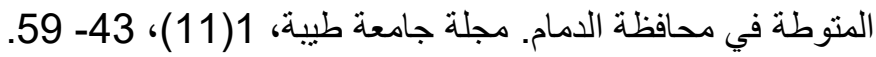

مصطفى رجب ـ (1995). التقويم التربوي تطورات واتجاهات مستقلية. المجلة العربية للتربية، 15 (2)، 15 (2)، 8- 25. موقع التعليم في مدينة القس. (بلا تاريخ). التعليم في مدينة القدس. تم الاسترداد من /https://www.jerusalem.muni.il/ar/residents/education/elementaryschools

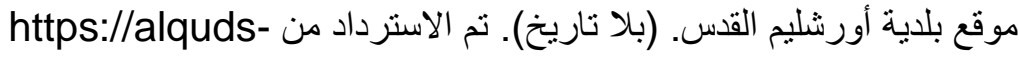
org.blogspot.com/2013/01/blog-post.html

هشام بني خلف. (2019). اتجاهات معلمي التربية الميدانية بمحافظة شرورة نحو توظيفهم لأساليب التقويم الو اقعي في

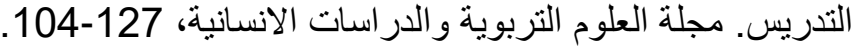

وصال العمري، و فواز شحادة. (2010). درجة رضيا معلمّمي العلوم عن توظيف أساليب التّقويم الو اقعي في تقويم

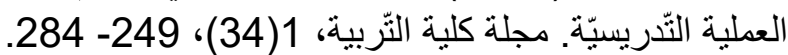

\section{قائمة المراجع الأجنبية}

Broadfoot, P. (2004). Redefining Assessment, The First ten Years of Assessment in Education. Principle, Policy \& Practice, 11(1), 7 - 26.

Caseley, P. (2004). Toward an Authentic Learning Instruction in Middle School. Pacific Lutheran University.

Craw, K. (2009). Performance Assessment Practices A Case Study of Science Teacher in Suban High school Setting.

Etsey, Y. (2000). Teacher Education Perception of Classroom and Standardized Assessment. Dissertation Abstract International, 60(9).

Gulikers, J., Bastiaens, T., \& Martens, R. (2005). The Surpulus Value of An Authentic Learning Environment. Computers in human Behavior, 21(3), 509- 521.

Hammod, L. (2004). Standards, Accountability, and School Reform. (U. Columbia, Ed.) Teachers College Record, 106, 1047- 1085.

Moon, T., Brighton, C., Callahan, C., \& Robinson, A. (2005). Development of Authentic Assessments For The MiddleSchool Classroom. XVI,2/3(A), 119 - 133.

Mueller, J. (2009). Authentic Assessment Toolbox. Retrieved 2 17, 2019, from www,fmueller.noctrl 